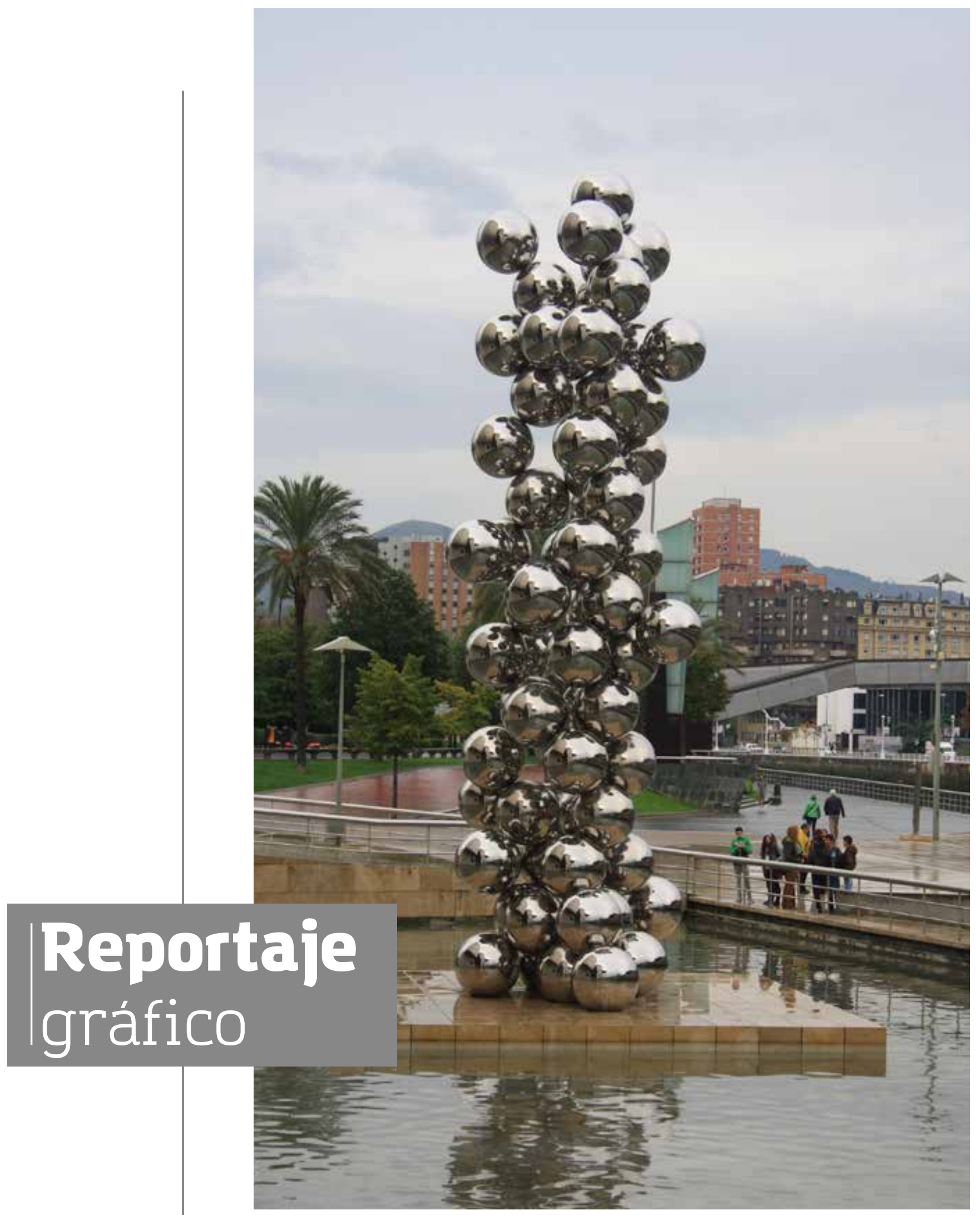




\section{Experiencias internacionales: desde Montería al Viejo Continente}

https://doi.org/10.18566/comunica.n45.a08

Recibido: 28 de abril de 2021

Aceptado: 31 de mayo de 2021

Como política de internacionalización de la universidad y con el fin de propiciar la movilidad internacional de los estudiantes, en el año 2017 se llevó a cabo una gira académica: la experiencia de los programas de Comunicación Social Periodismo y de Arquitectura de Montería extendió las fronteras hacia el Viejo Continente, recorriendo ciudades como Madrid, Barcelona, Bilbao y Santiago de Compostela en España, además de Oporto y Lisboa en Portugal.

La gira comenzó en Madrid, una ciudad moderna y tradicional, majestuosa y popular, animada y tranquila, pero sobre todo hospitalaria y diversa. Como actividad cultural y turística visitaron los sitios de interés más representativos.

En la programación académica de esta ciudad hubo visitas a universidades y medios de comunicación, como la empresa Atresmedia, donde luego del recorrido por las instalaciones, asistieron a programas que estaban emitiendo en directo; en el periódico El País, los estudiantes tuvieron contacto con periodistas que compartieron sus experiencias, metodología y estilo de trabajo. Con la Universidad Europea de Madrid hubo contactos para la celebración de un convenio cuyo fin era propiciar la movilidad estudiantil y docente.

El siguiente destino fue Barcelona, capital de Cataluña, región del norte de España con su propia cultura y personalidad. Allí pudieron apreciar sus amplias avenidas, monumentos y edificaciones más famosas, así como la diversidad cultural y sus encantadoras playas.

En la Universidad de Barcelona compartieron con los estudiantes locales y presentaron trabajos realizados en los cursos de ambos programas. En la Escuela de Bellas Artes hicieron la entrega de las fotografías de una serie titulada Quehaceres Caribe: mundo cultural por imaginar, de los diferentes proyectos del semillero Formas y Formatos del programa de Comunicación Social; además de la muestra Color Caribe, con fotos características del color y textura del Caribe 
colombiano visto a través de los ojos de algunos profesores de la Facultad de Arquitectura; estas fotografías fueron donadas a la Universidad de Barcelona y posteriormente montaron con ellas una muestra.

En los 90, Bilbao estaba en medio de una gran crisis social y económica y en menos de una década se transformó en un referente de modernidad por su actividad cultural y su calidad de vida. En esta bella y limpia ciudad visitaron sitios como el centro, el puerto, el Museo Guggenheim y la Universidad de Deusto, donde participaron en una charla sobre cómo fue ese proceso de transformación de la ciudad y cómo convirtió esta a la ría en su centro de actividades.

La gira continuó hacia la ciudad de Santiago de Compostela, Patrimonio de la Humanidad desde 1985; su catedral es conocida como la culminación de las diferentes rutas de peregrinación del Camino de Santiago. Destacan los edificios históricos y sus plazas, dentro de paredes medievales. En los últimos tiempos han construido grandes obras de arquitectura contemporánea que le han dado un gran contraste a esta ciudad, entre las que está la Ciudad de la Cultura, un complejo arquitectónico diseñado por Peter Eisenman en la cima del monte Gaiás compuesto por varios edificios y espacios orientados a temas culturales y de entretenimiento. Su construcción fue suspendida a finales de marzo de 2013, por lo que dos de los edificios proyectados (un Teatro de la Ópera y un Centro de Arte Internacional) no fueron levantados.

La próxima ciudad fue Oporto, una de las más bellas y ricas de Portugal, conocida por sus imponentes puentes y sus vinos mundialmente famosos; así como por el centro histórico, donde se encuentran los monumentos más emblemáticos: la Plaza de los Aliados, la Casa de la Música, la Fundación Serralves, la rua de Santa Catarina.

En la visita a la Universidad de Oporto llevaron a cabo gestiones para la realización de un convenio de intercambio estudiantil y docente.

Y no podía faltar la visita Lisboa, la capital de Portugal, una ciudad que a lo largo de los años ha recibido diversas culturas venidas de lejanos lugares, como los cristianos, los árabes y los judíos, que le dan un contraste encantador. Se pueden recorrer los barrios históricos, las calles del distrito de Baixa, la zona de Belém, con monumentos de patrimonio universal, barrios medievales y también zonas contemporáneas.

De regreso a Madrid fueron hasta el Santuario de la Virgen de Fátima, un lugar muy importante para los católicos de todo el mundo. 
Comunicación

número 45

Julio - diciembre

No cabe duda de que esta actividad aportó mucho a los estudiantes y profesores: conocieron de primera mano cómo es la formación y cuáles son las tendencias y la aplicación de su profesión en otros países; además, ampliaron su bagaje cultural.

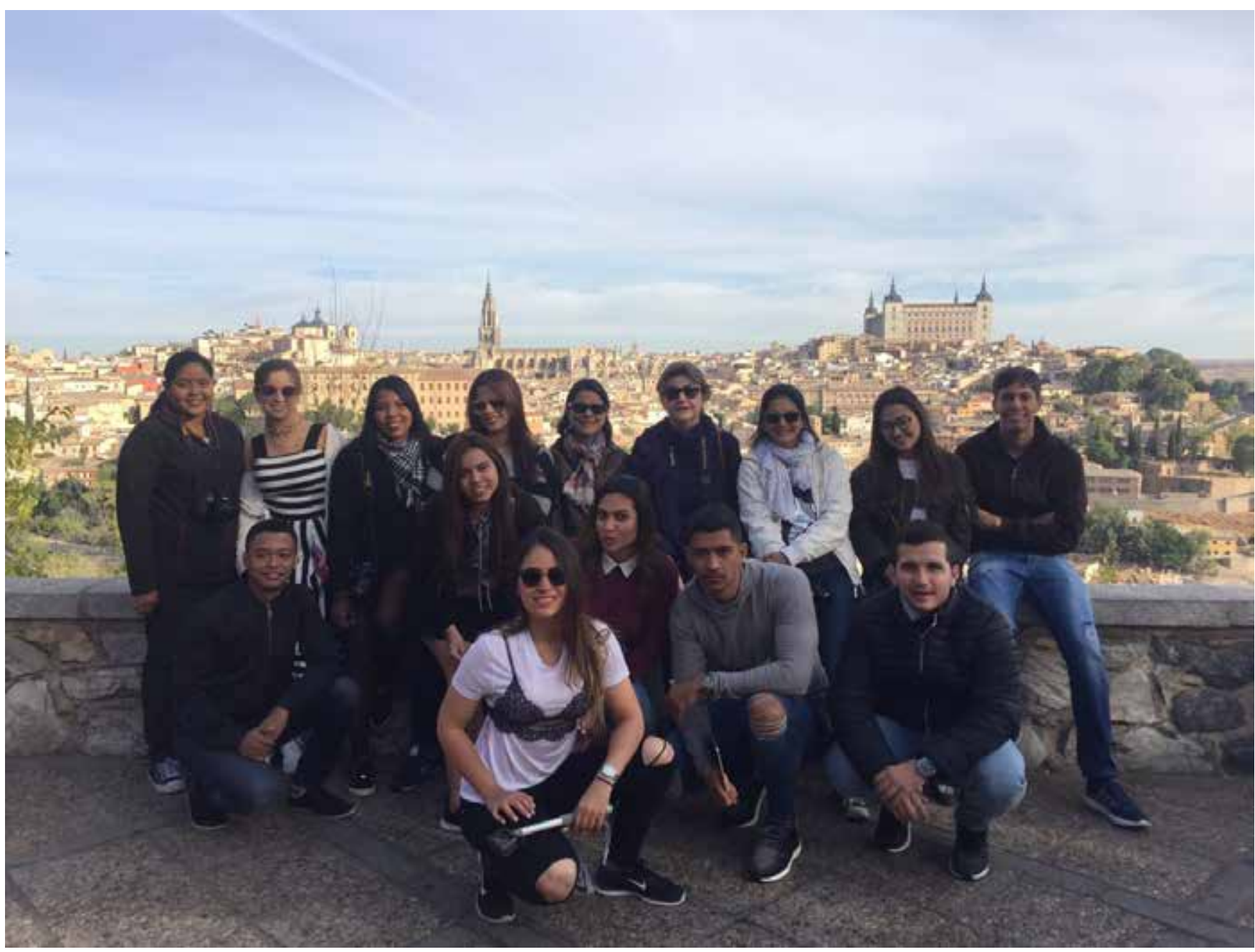




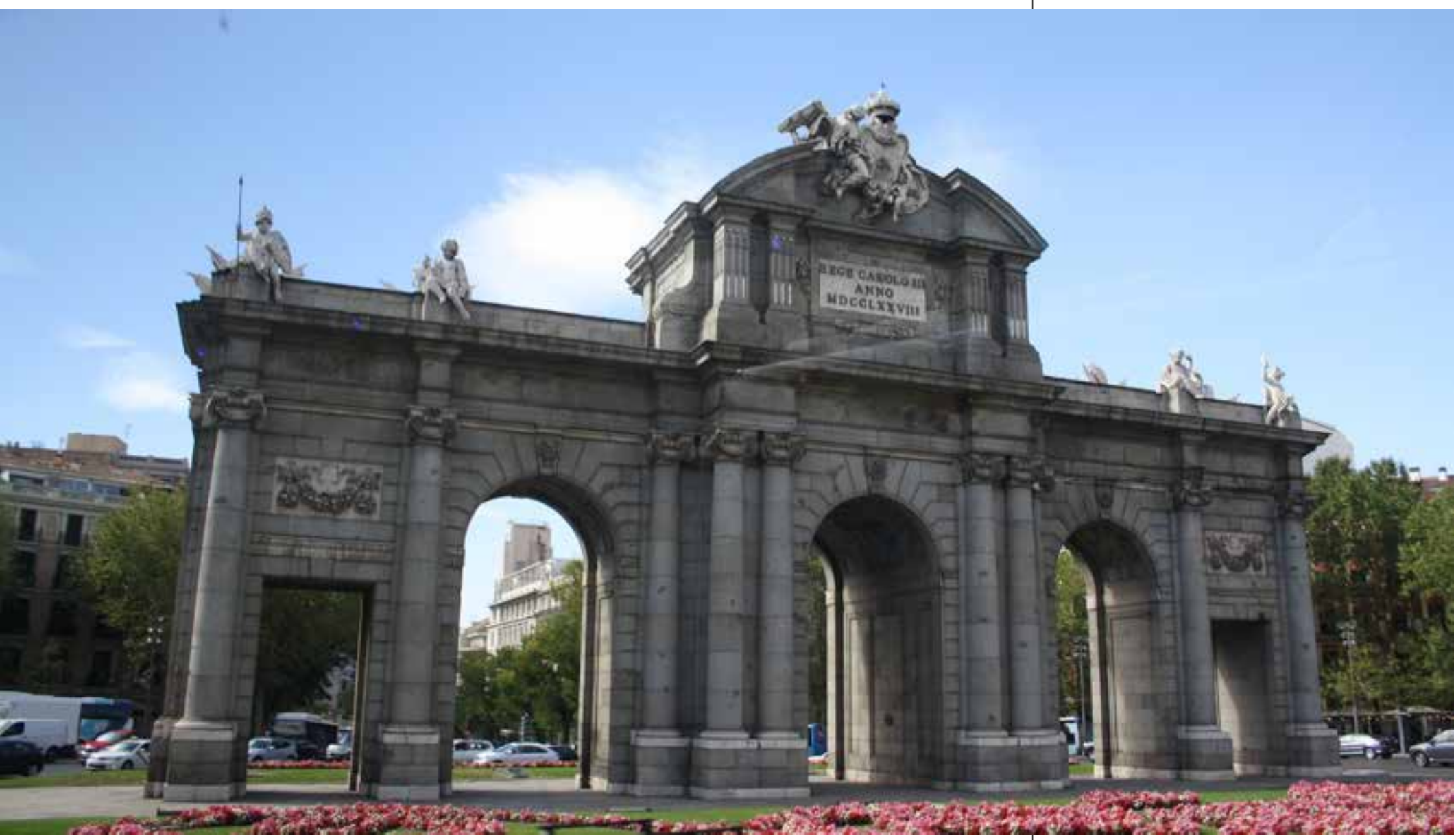


comunicación

número 45

Julio - diciembre

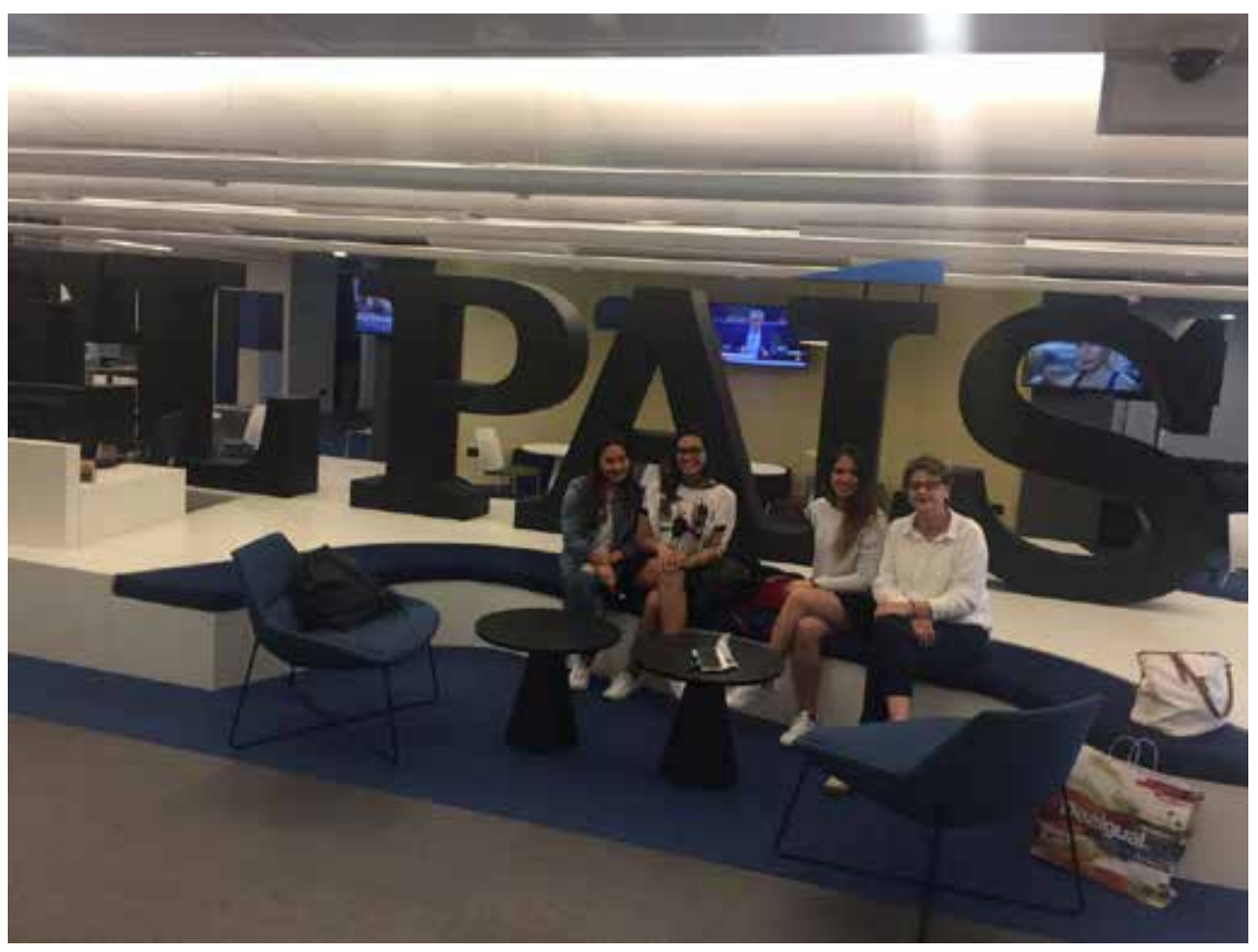

Tradicional Mercado de San Miguel. Madrid.

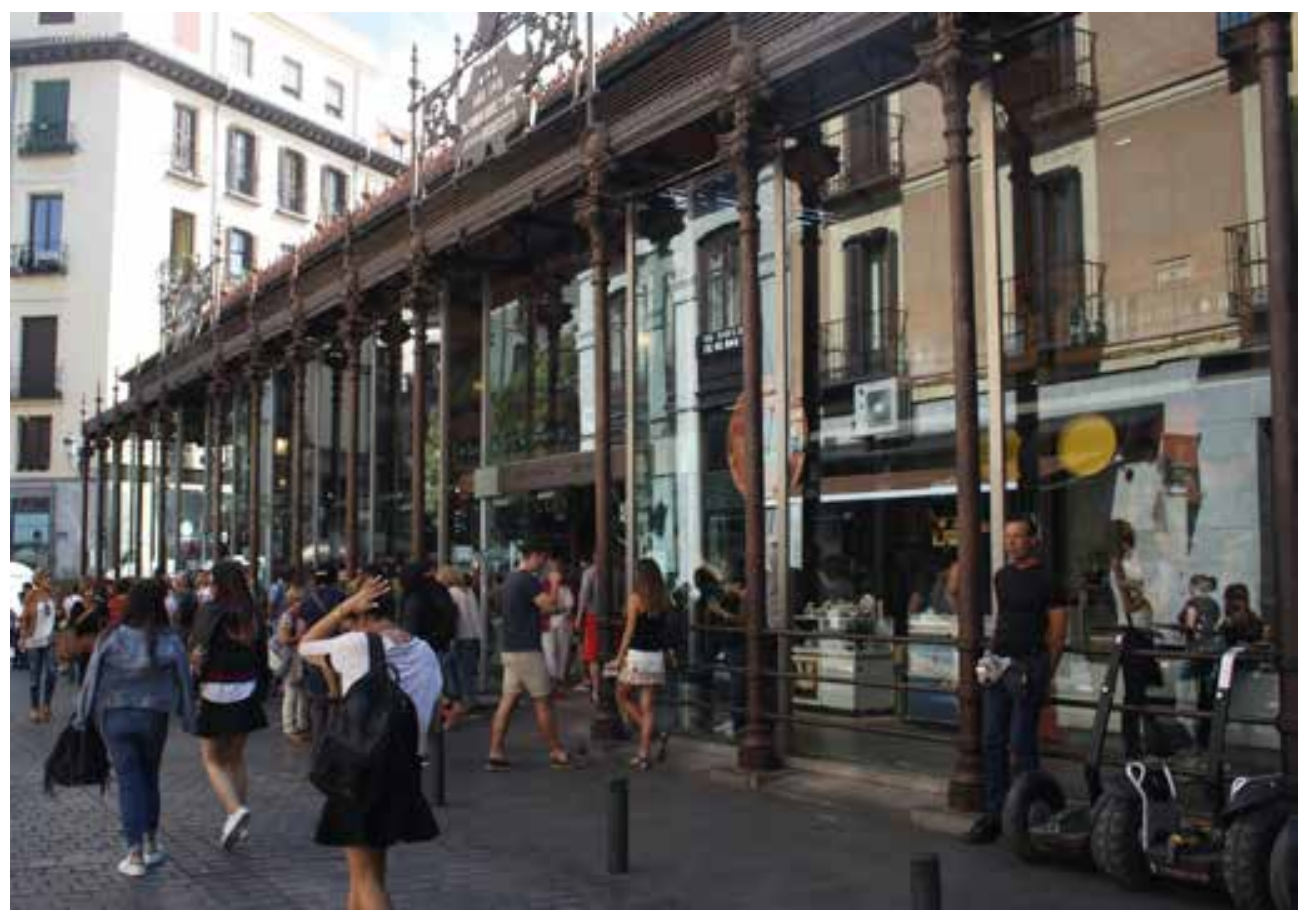


Comunicación

número 45

Julio - diciembre 
comunicación

número 45

Julio - diciembre

2021

Barrio Gótico, donde se aprecian calles angostas, plazas e iglesias del glorioso pasado de la ciudad. Barcelona.

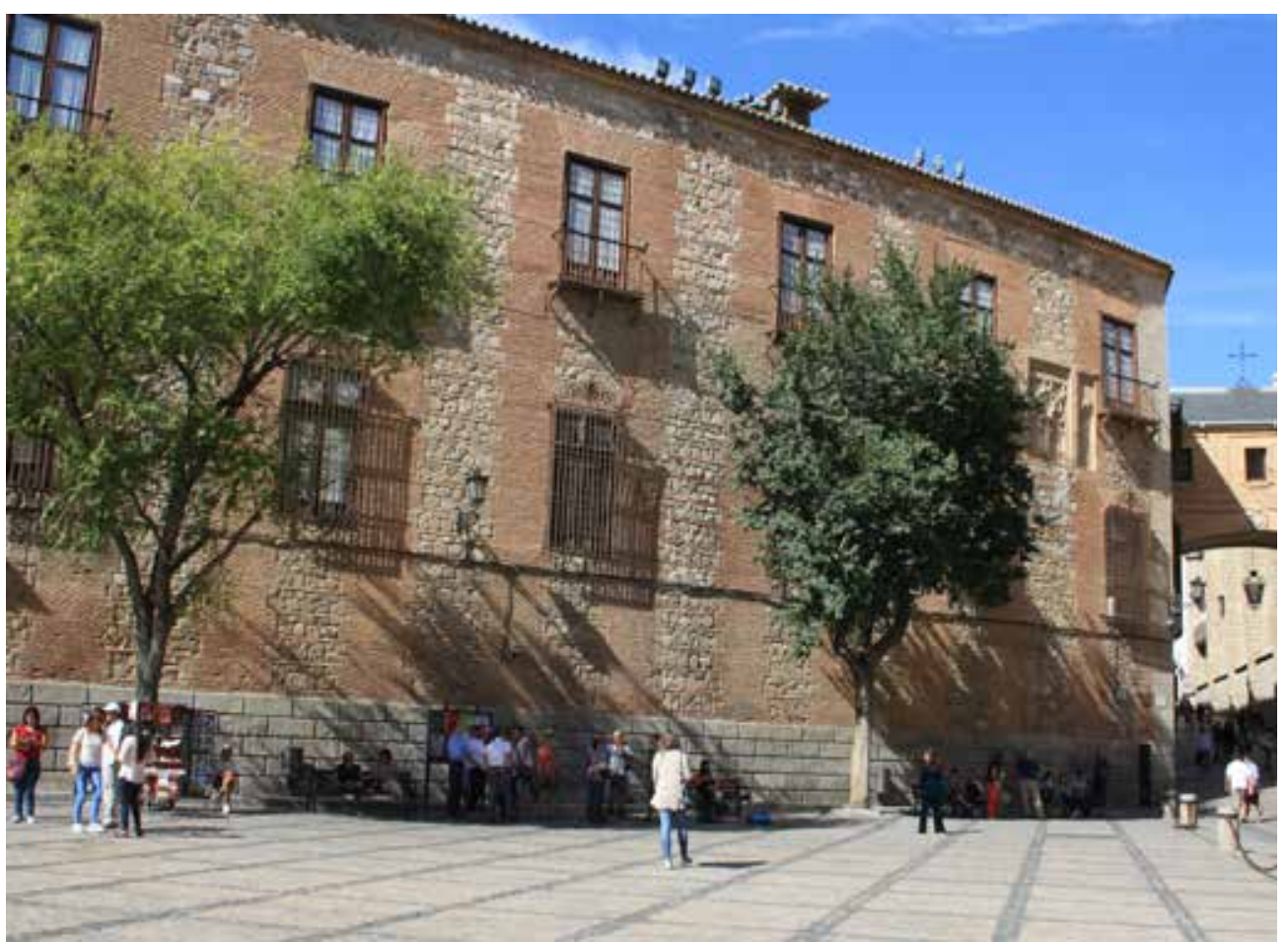

Antigua toma de agua en calle de Barcelona.

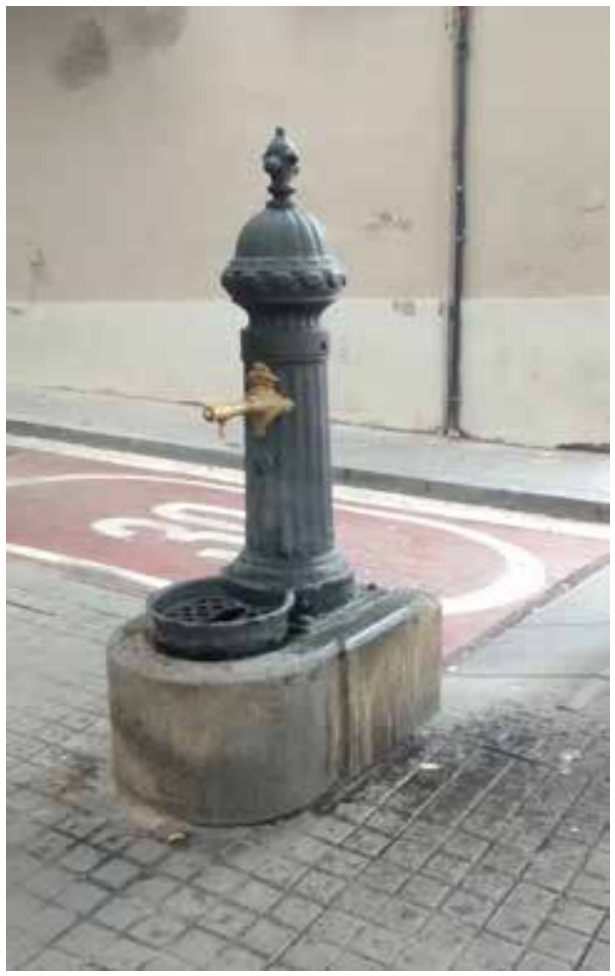



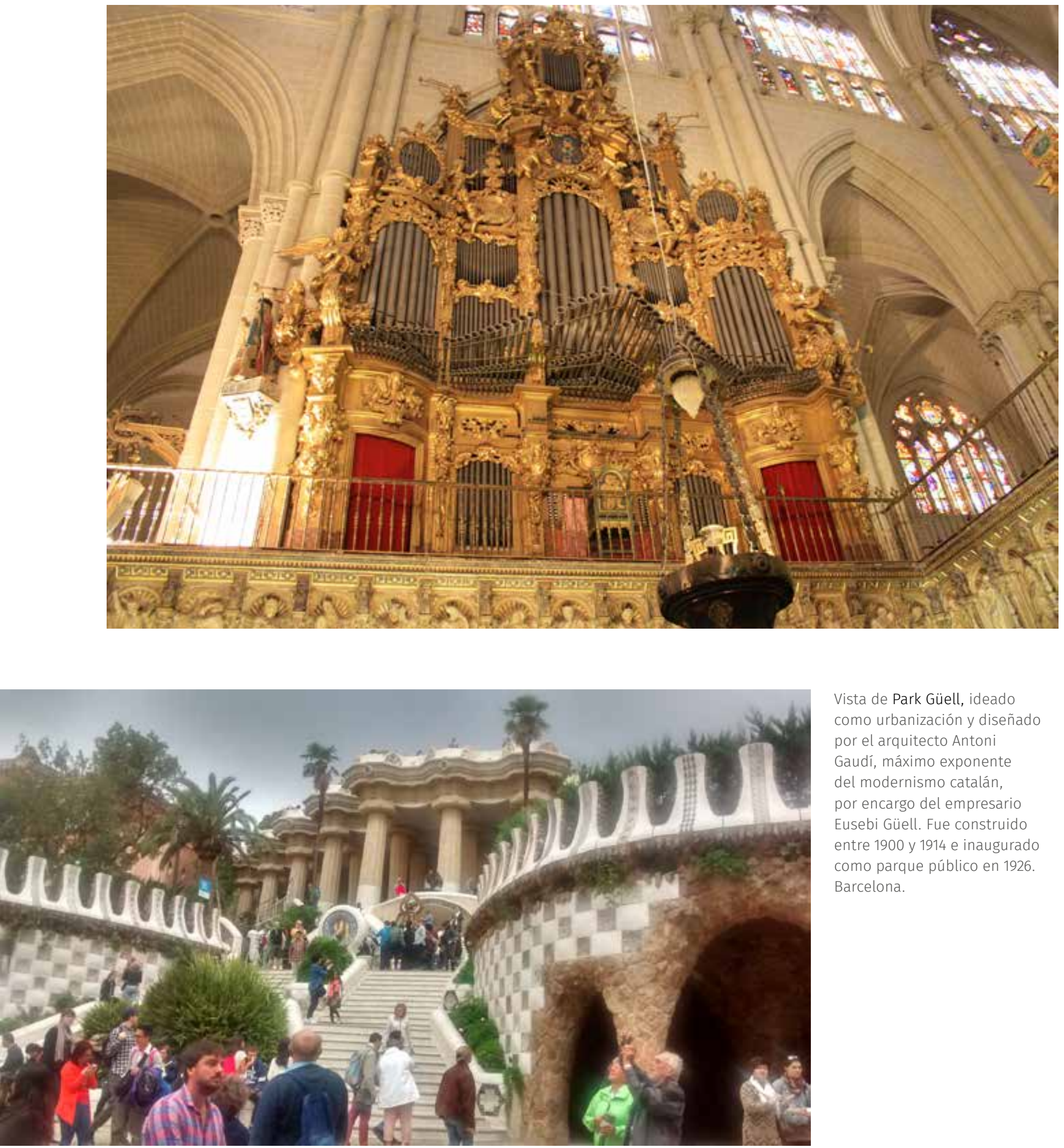

Vista de Park Güell, ideado como urbanización y diseñado por el arquitecto Antoni Gaudí, máximo exponente del modernismo catalán, por encargo del empresario Eusebi Güell. Fue construido entre 1900 y 1914 e inaugurado como parque público en 1926. Barcelona. 
Comunicación

número 45

Julio - diciembre

2021

Playa de la Barceloneta.

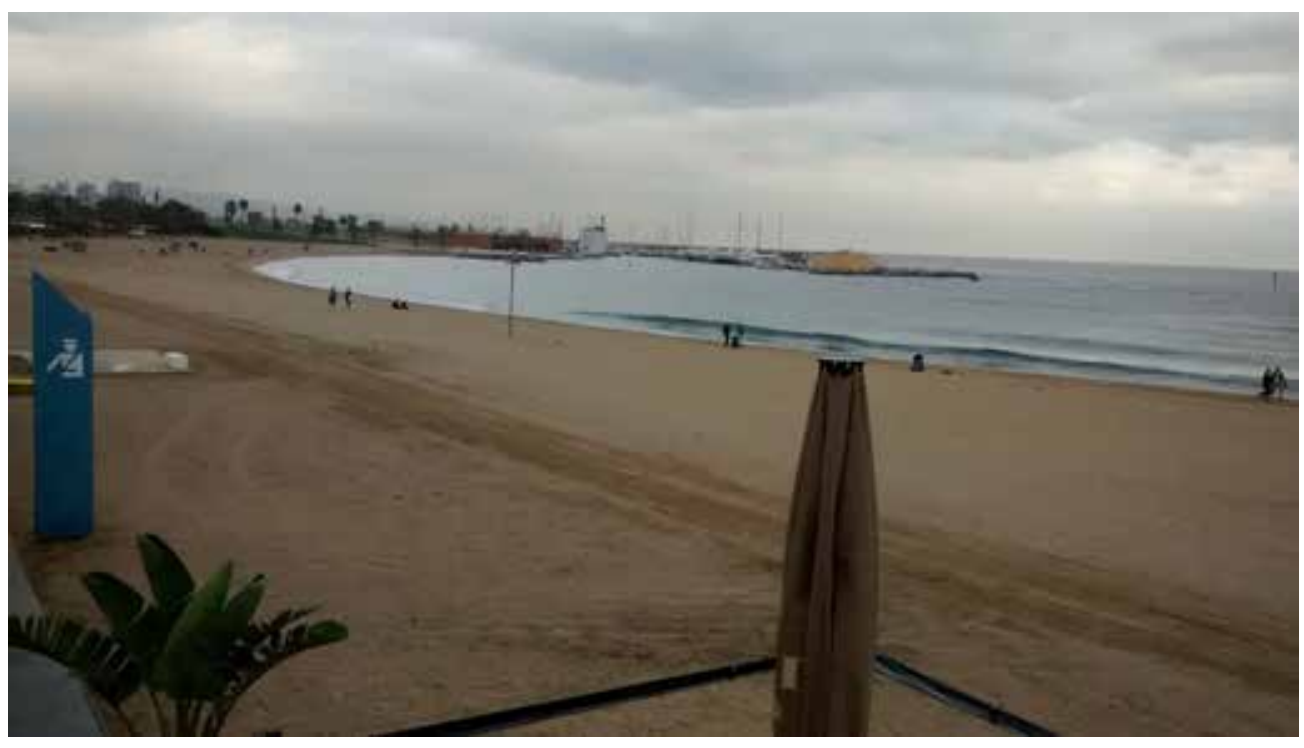

Reunión en la Escuela de Bellas Artes de la Universidad de Barcelona.

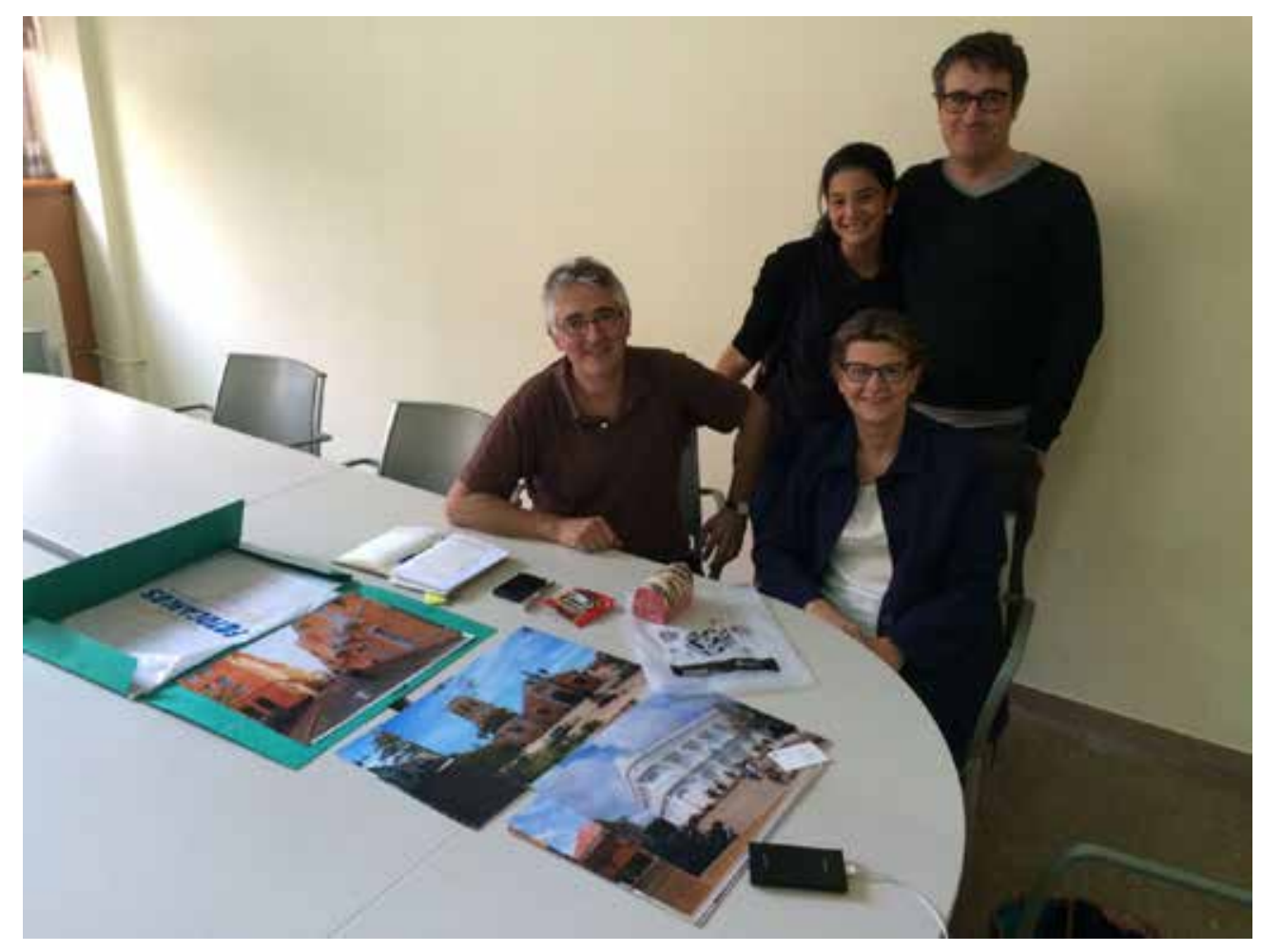




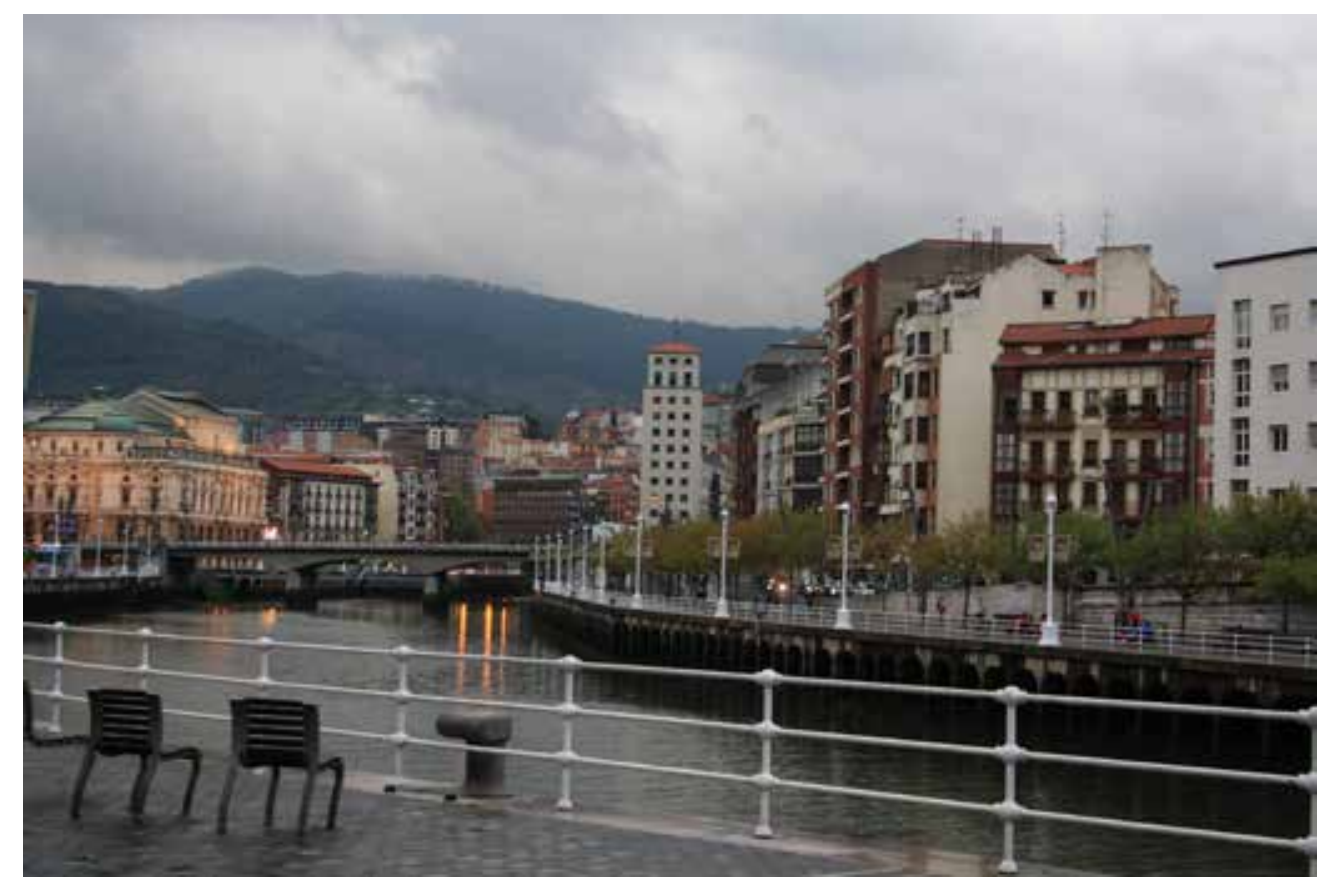

IMG. 13. Museo Guggenheim. Bilbao.

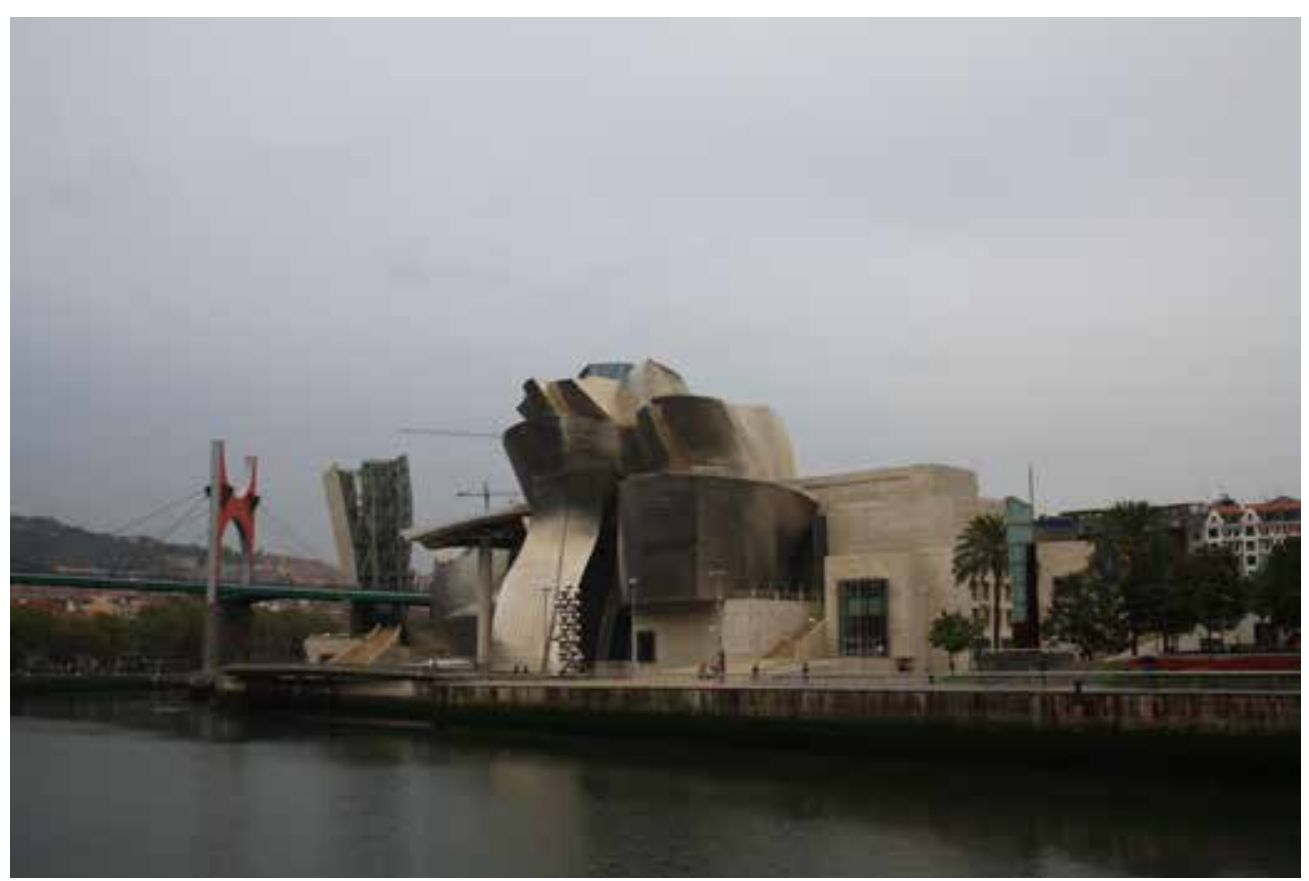


comunicación

número 45

Julio - diciembre

Vista externa de escultura en terraza sobre el río, en el Museo Guggenheim. Bilbao.

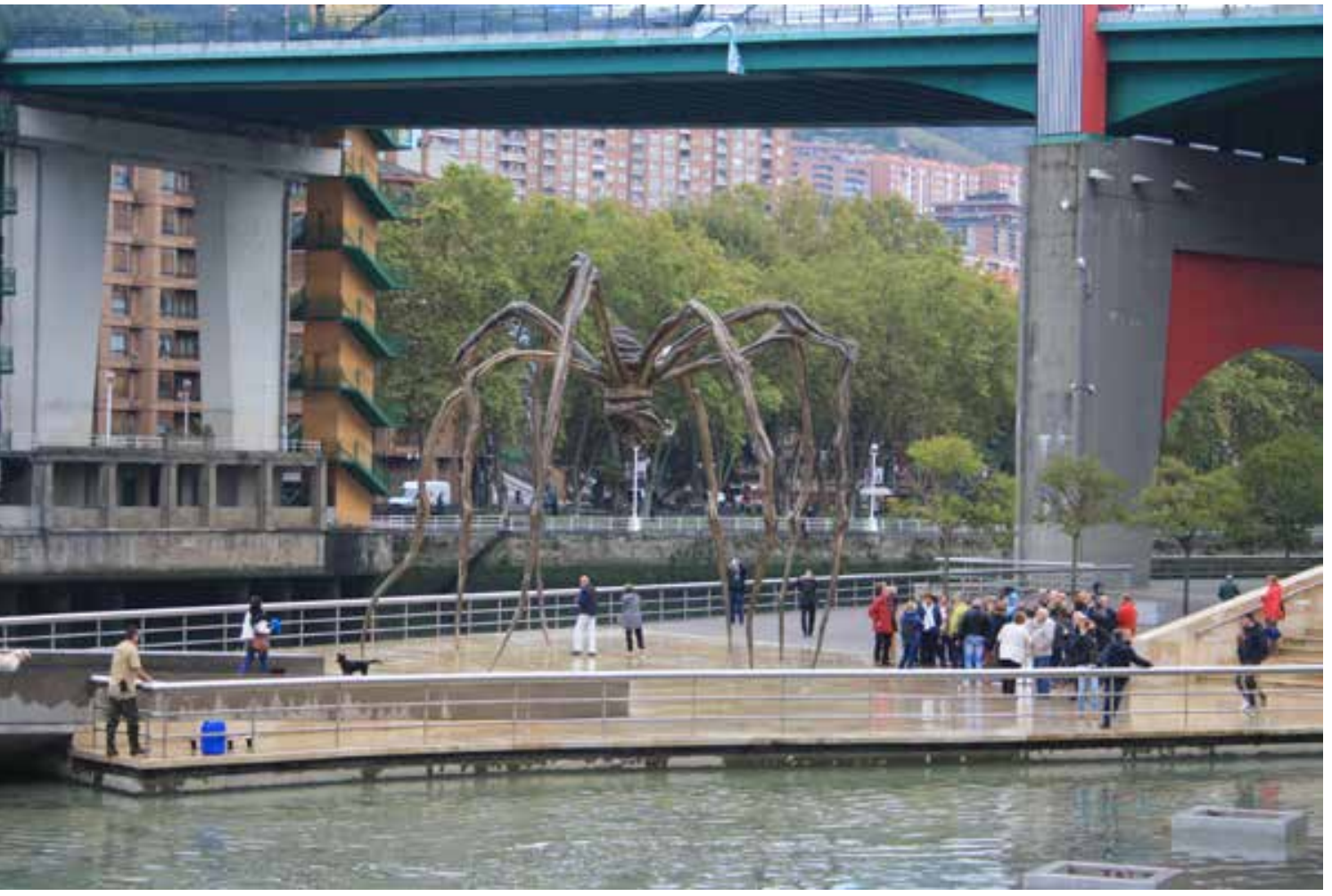

Vista interna de escultura en terraza sobre el río, en el Museo Guggenheim. Bilbao.

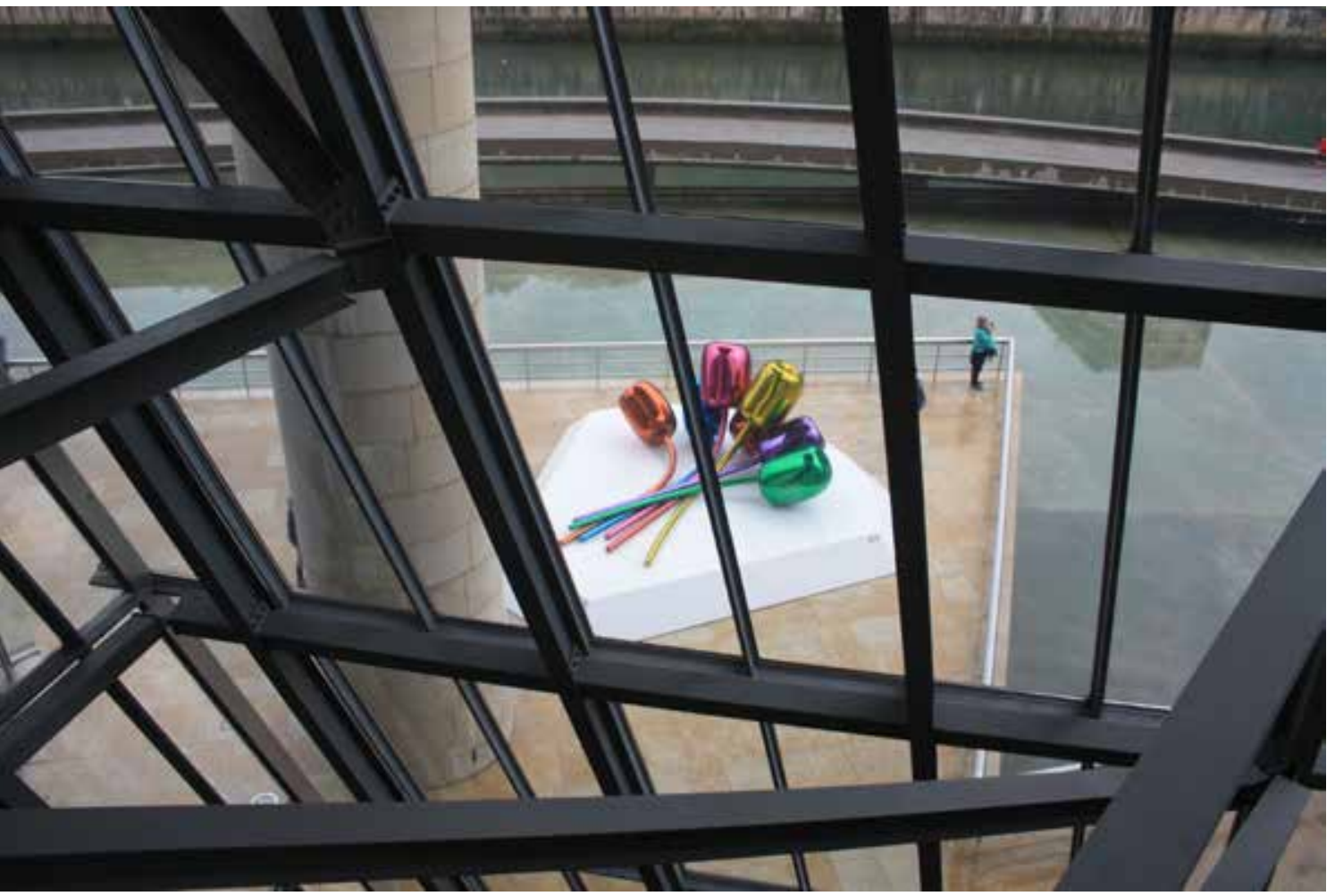




\section{8}

comunicación

número 45

Julio - diciembre

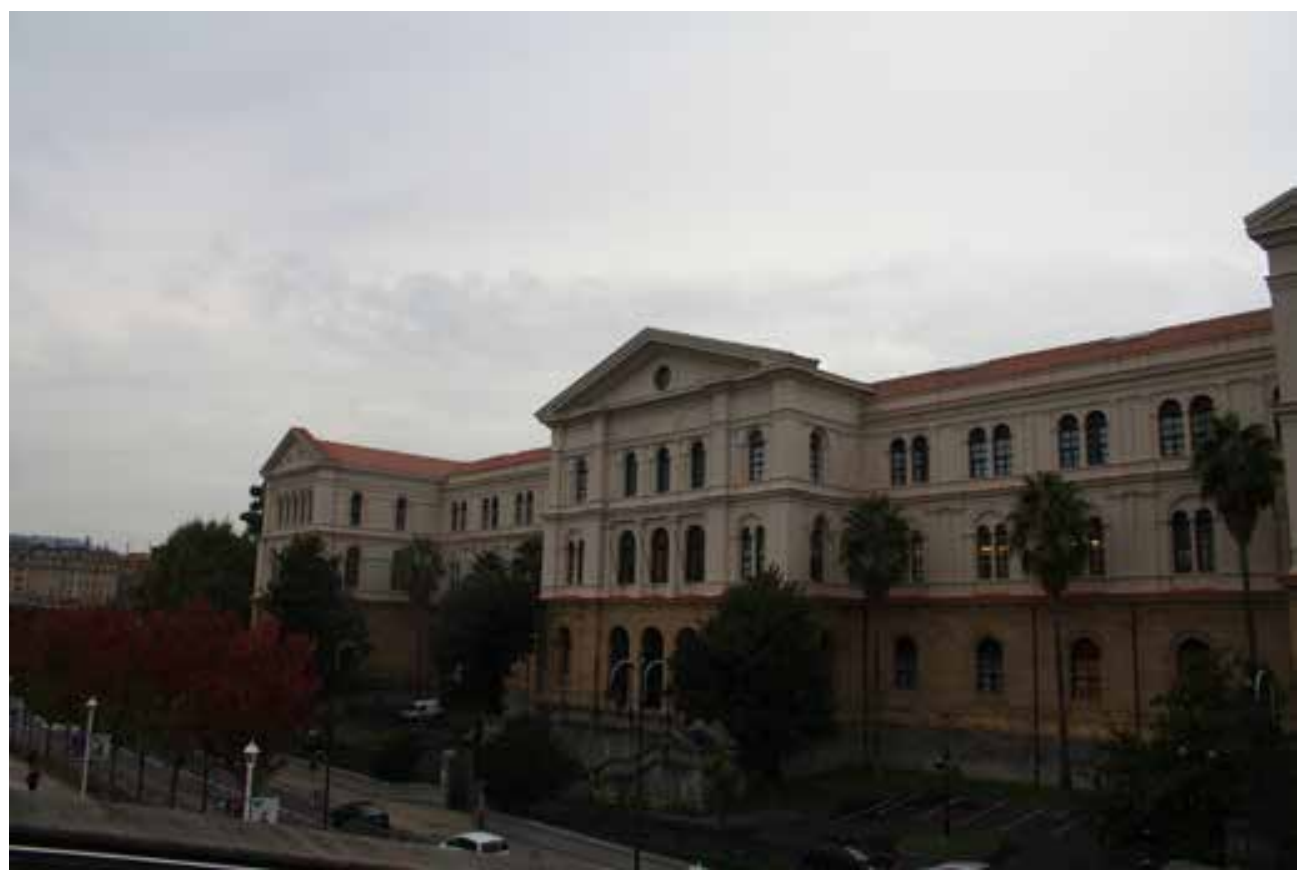

Acceso a las oficinas administrativas de la Universidad de Deusto. Bilbao.

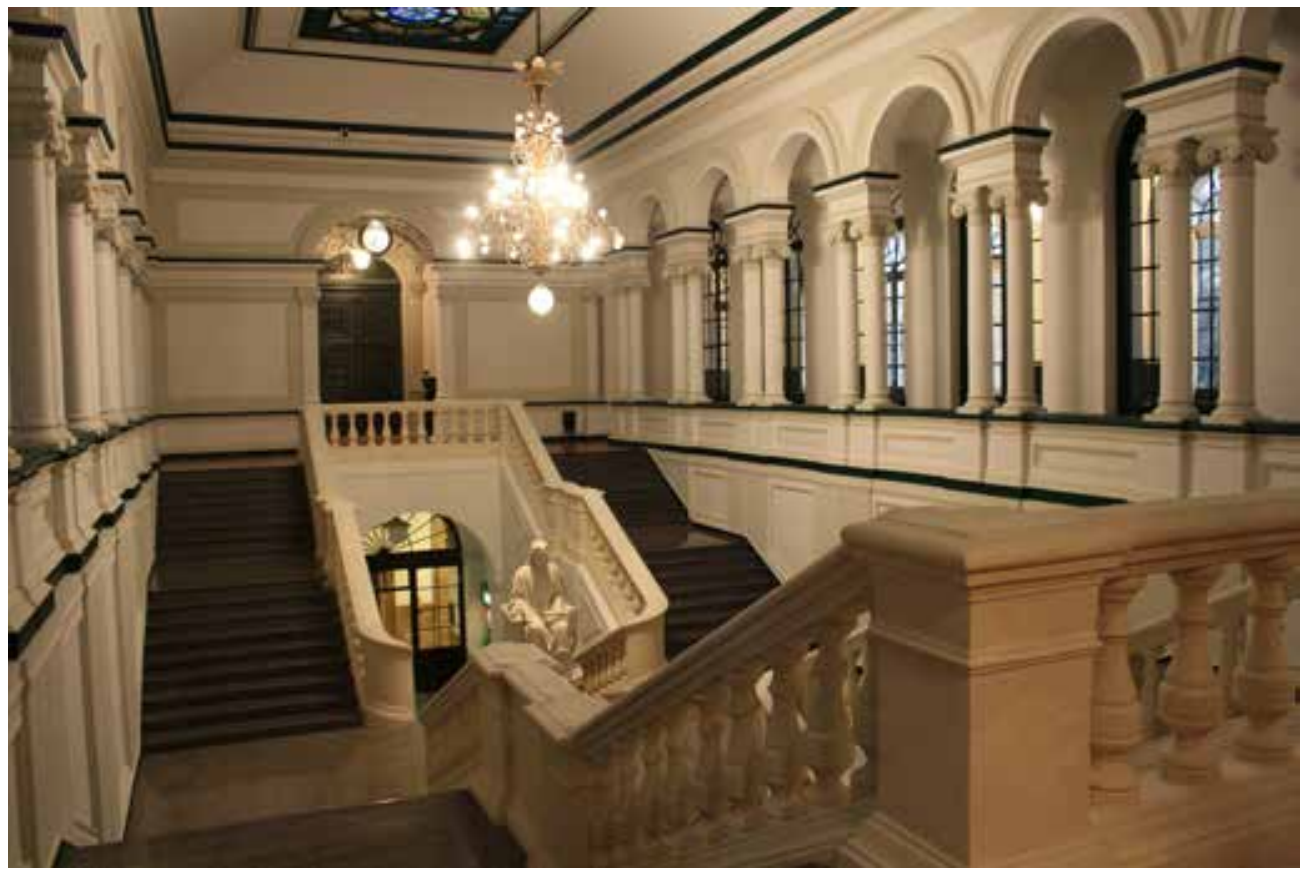




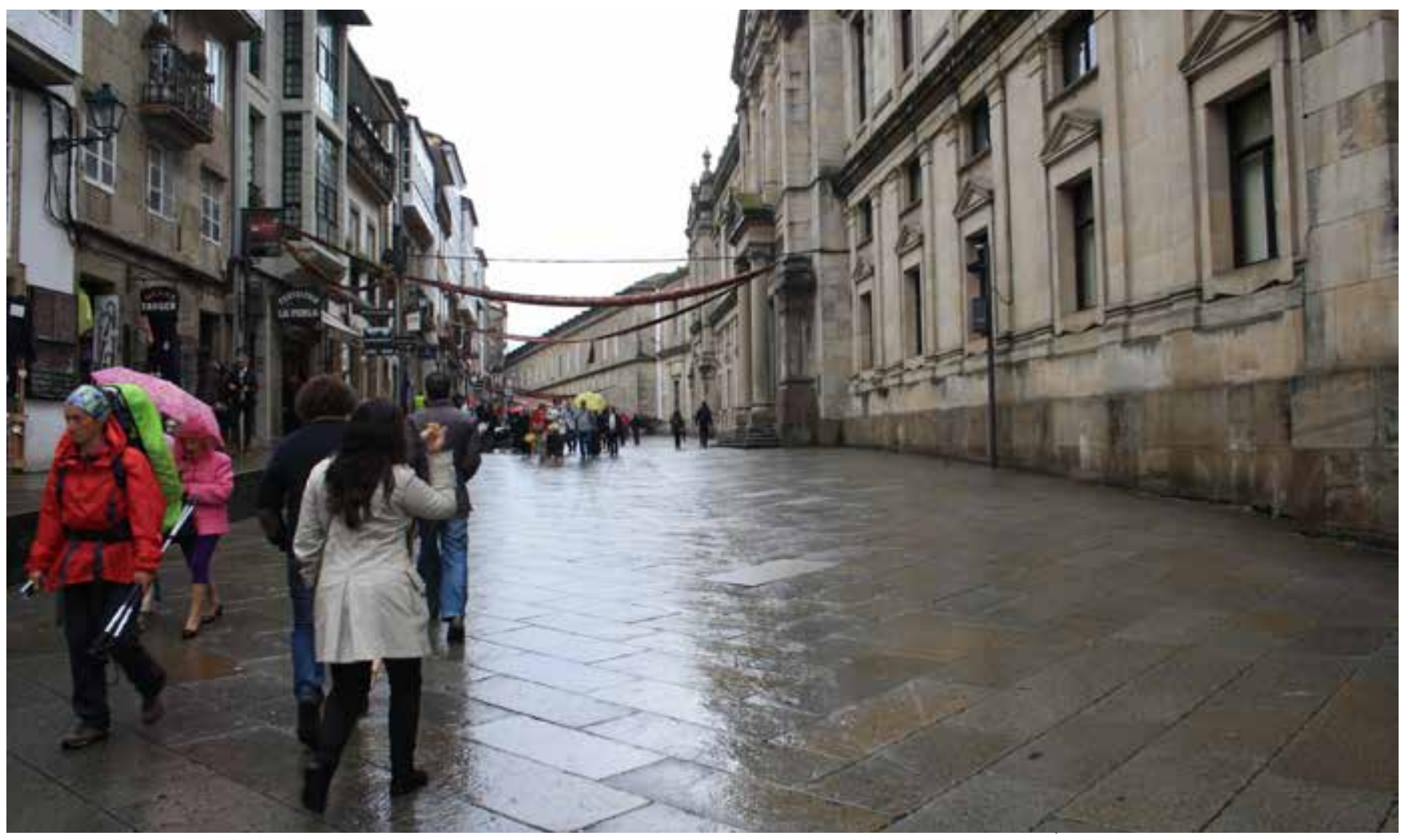

Entrada lateral a la Catedral de Santiago de Compostela.

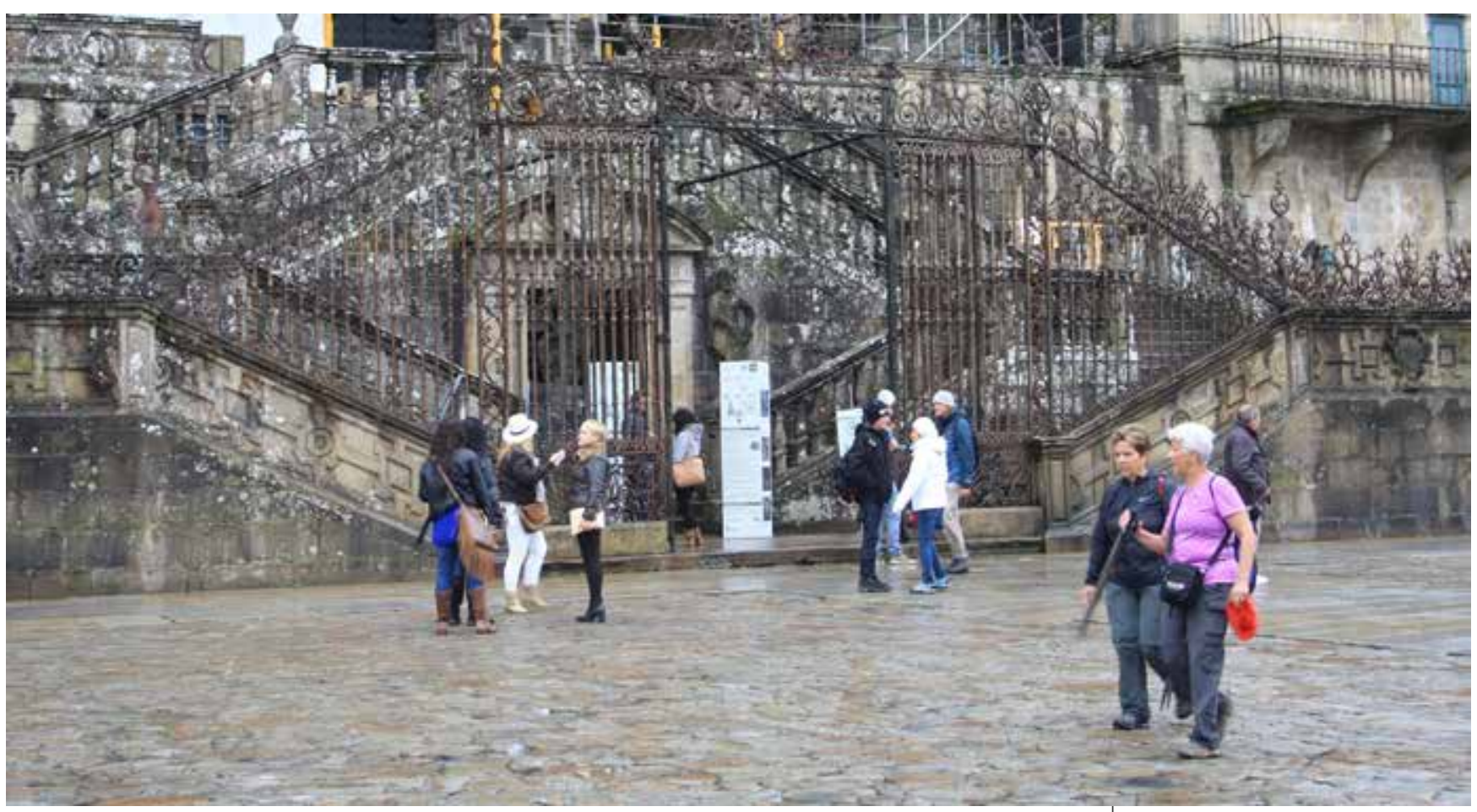




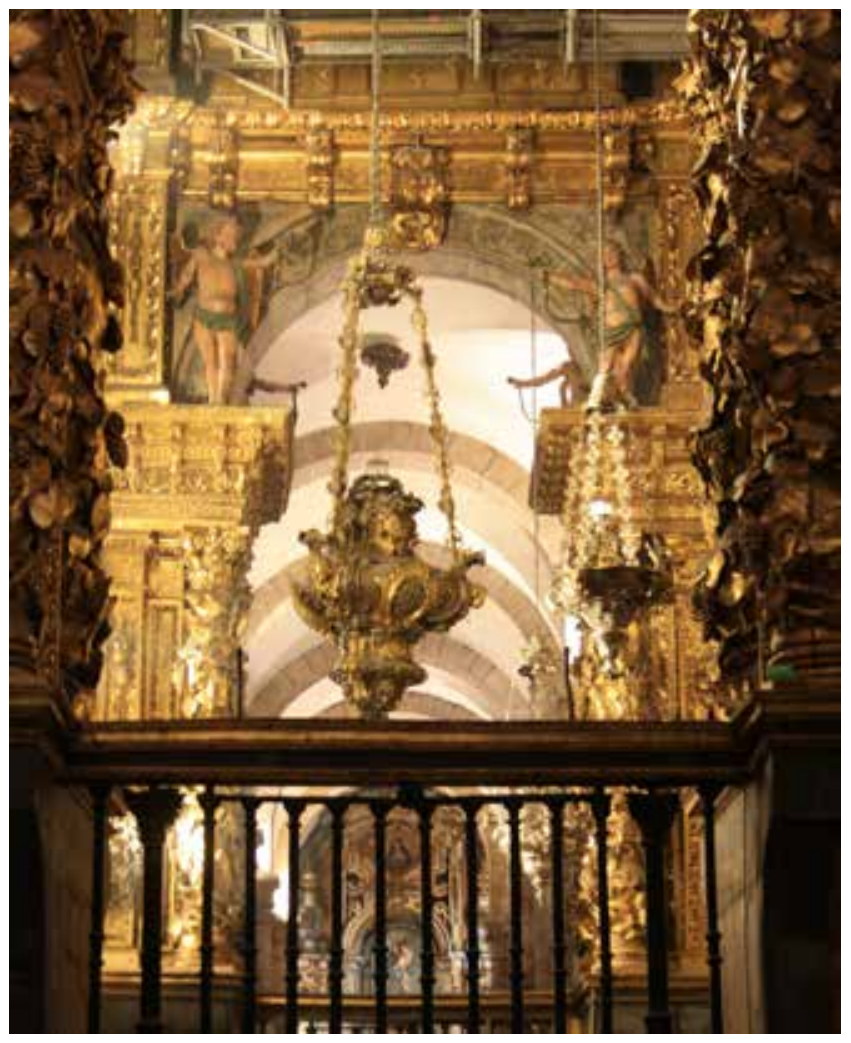

Uno de los símbolos más famosos de la Catedral de Santiago es el botafumeiro. Esta palabra se traduce literalmente del gallego como "el que echa humo". Se trata de un gran incensario de latón bañado en plata que tiene un peso de 62 kilos y una altura de 1,60 metros; desprende un peculiar aroma producto de la combustión de carbón junto a incienso. Según la tradición, el uso del incensario en la catedral comenzó en el siglo XI con la idea de perfumar el templo y eliminar el mal olor que dejaban los peregrinos cansados, sudorosos y desaseados, muchos de ellos enfermos.

Esculturas de santos en fachada de la Catedral de Santiago.

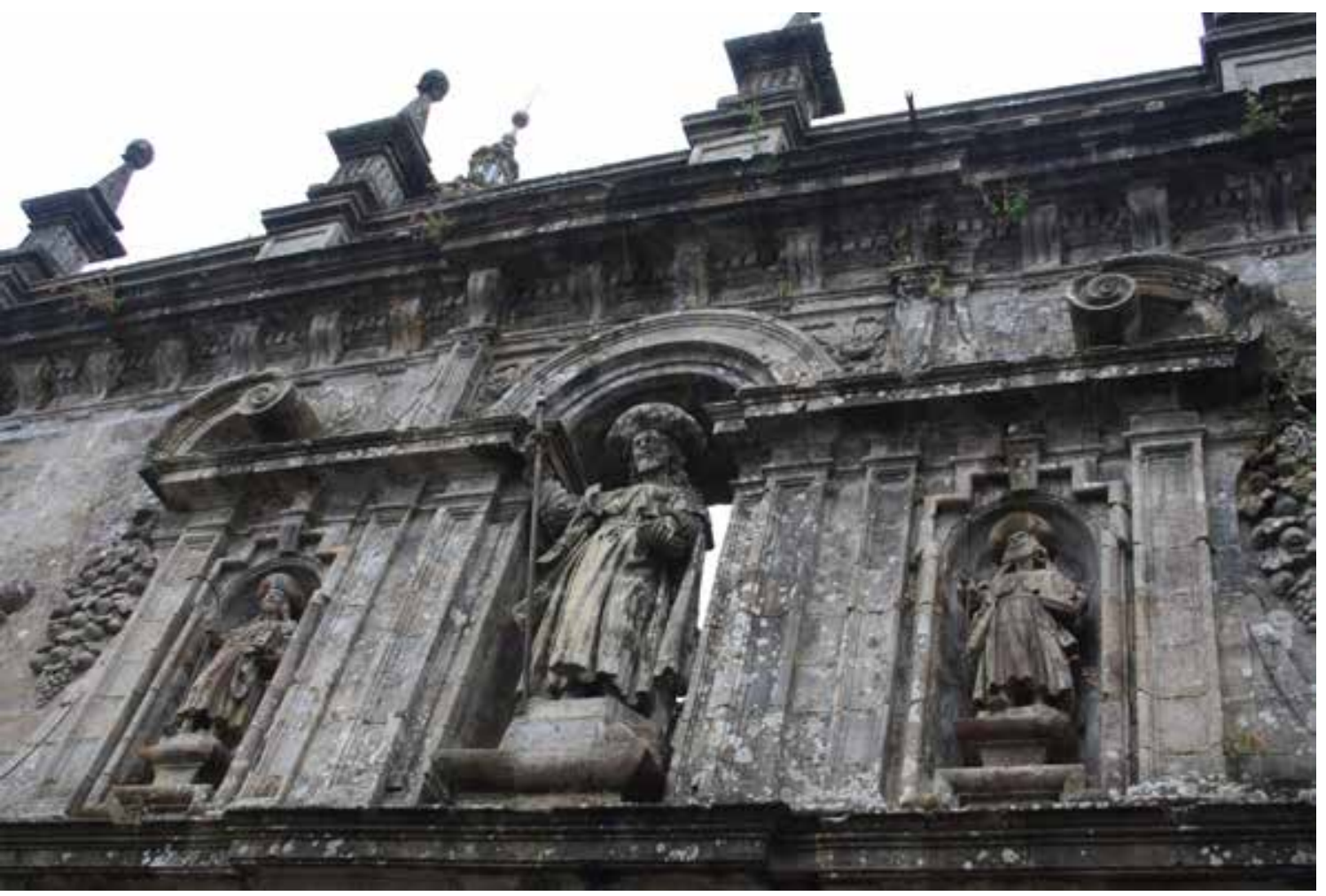


Exterior de la Ciudad de la Cultura, complejo arquitectónico diseñado por Peter Eisenman. Construido en la cima del monte Gaiás. Santiago de Compostela.

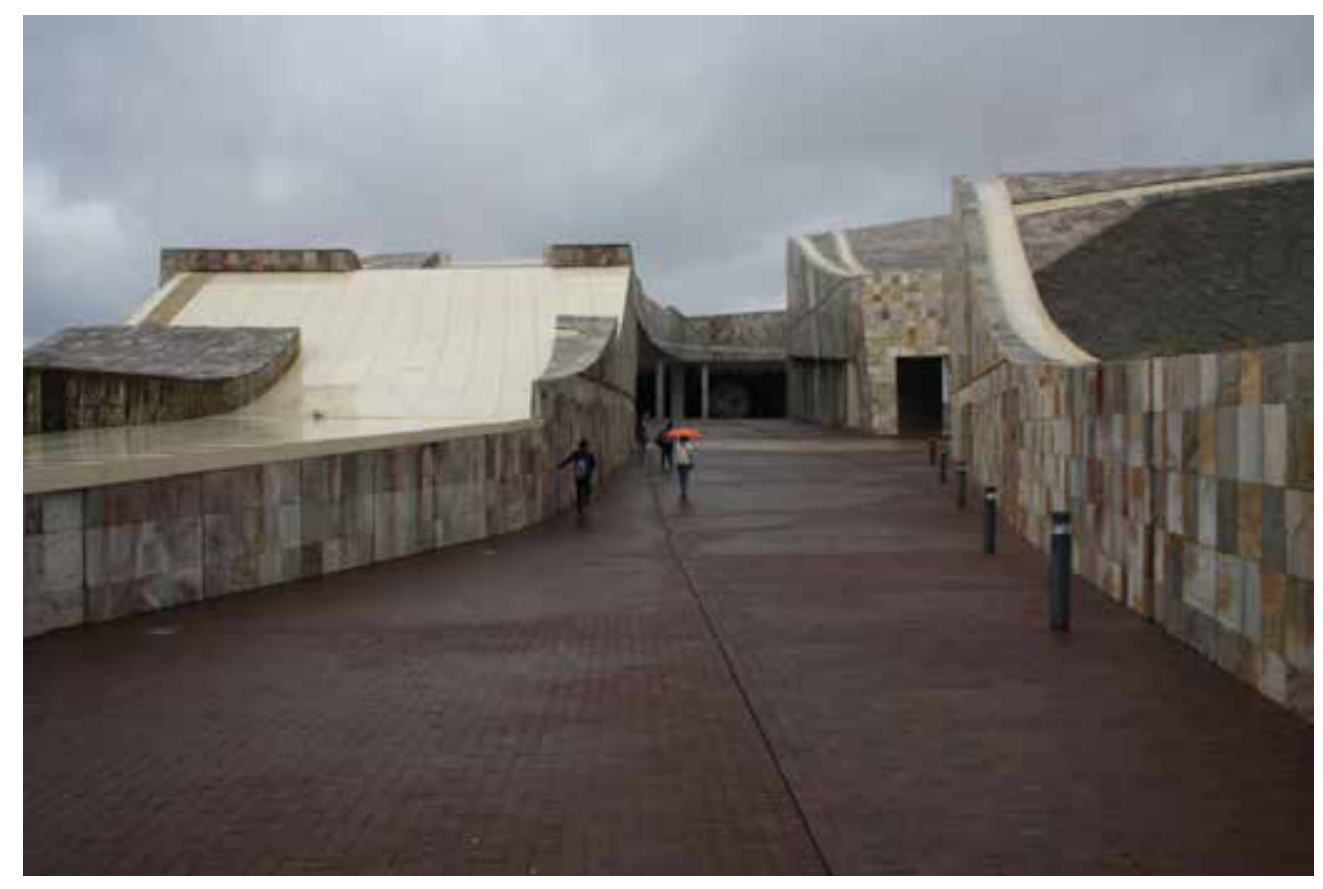

Interior de edificio de la Ciudad de la Cultura. Santiago de Compostela.

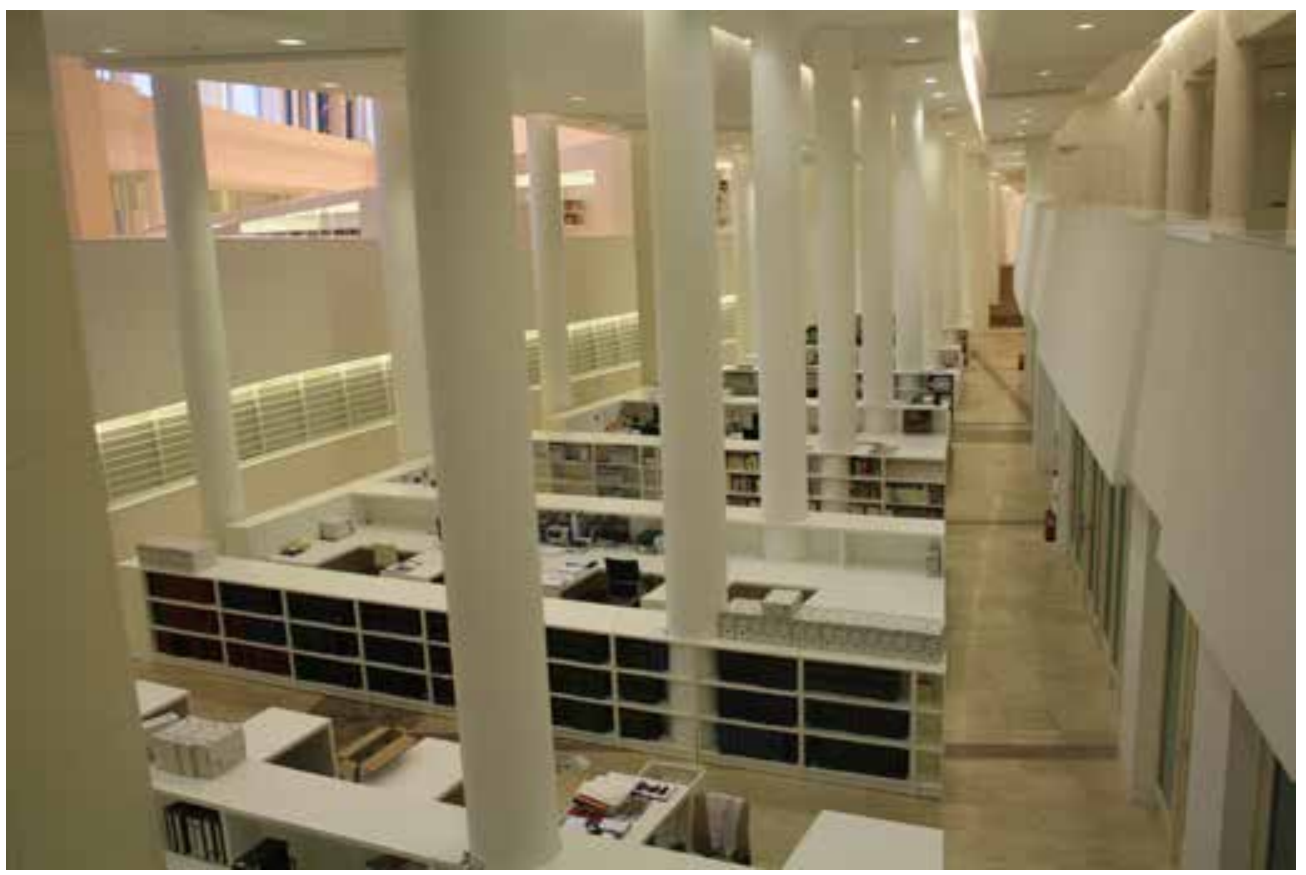


comunicación

número 45

Julio - diciembre

2021

Grupo de estudiantes y docentes en biblioteca de la Ciudad de la Cultura. Santiago de Compostela.
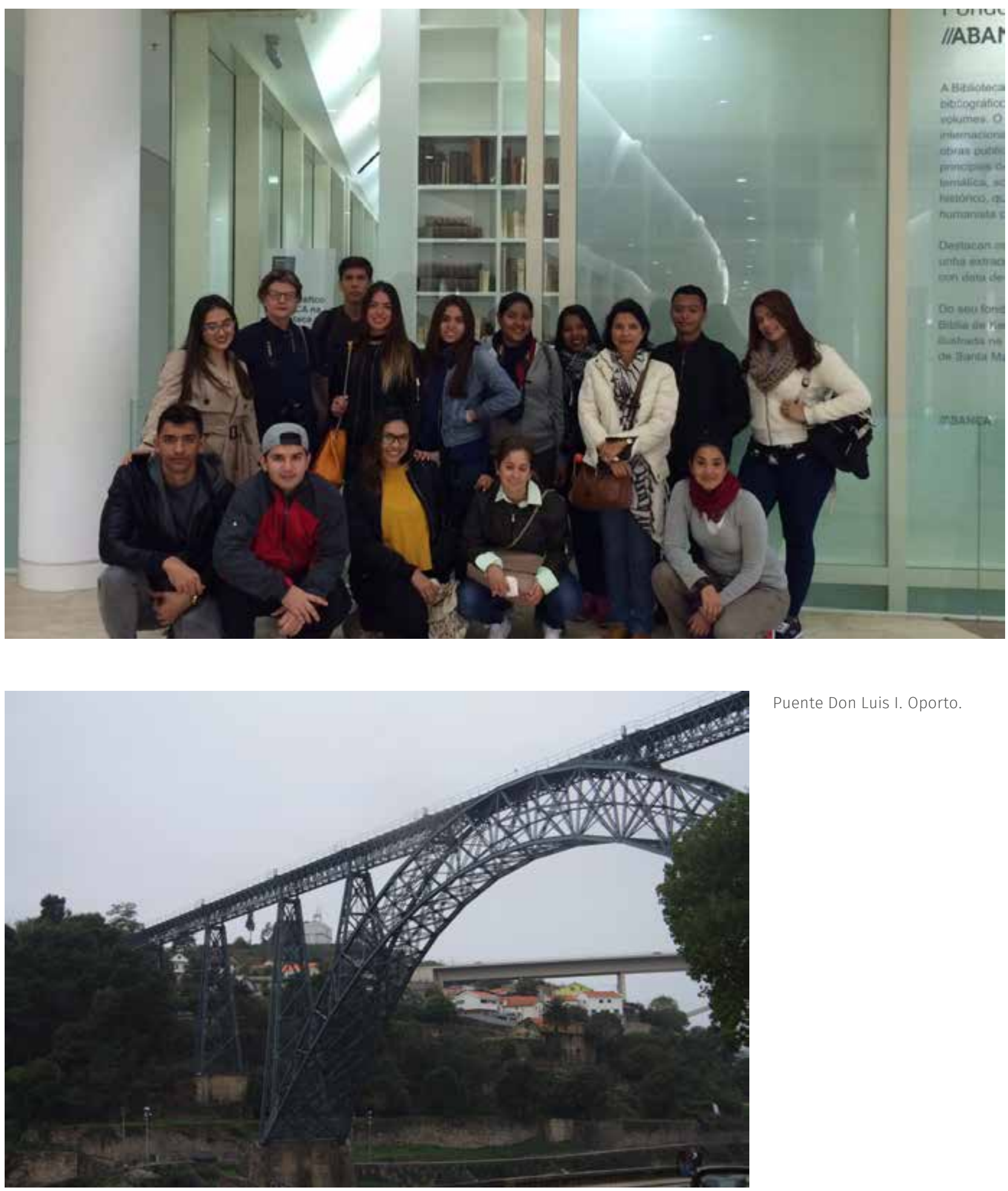

Puente Don Luis I. Oporto. 
comunicación

número 45

Julio - diciembre

Calle de Oporto.

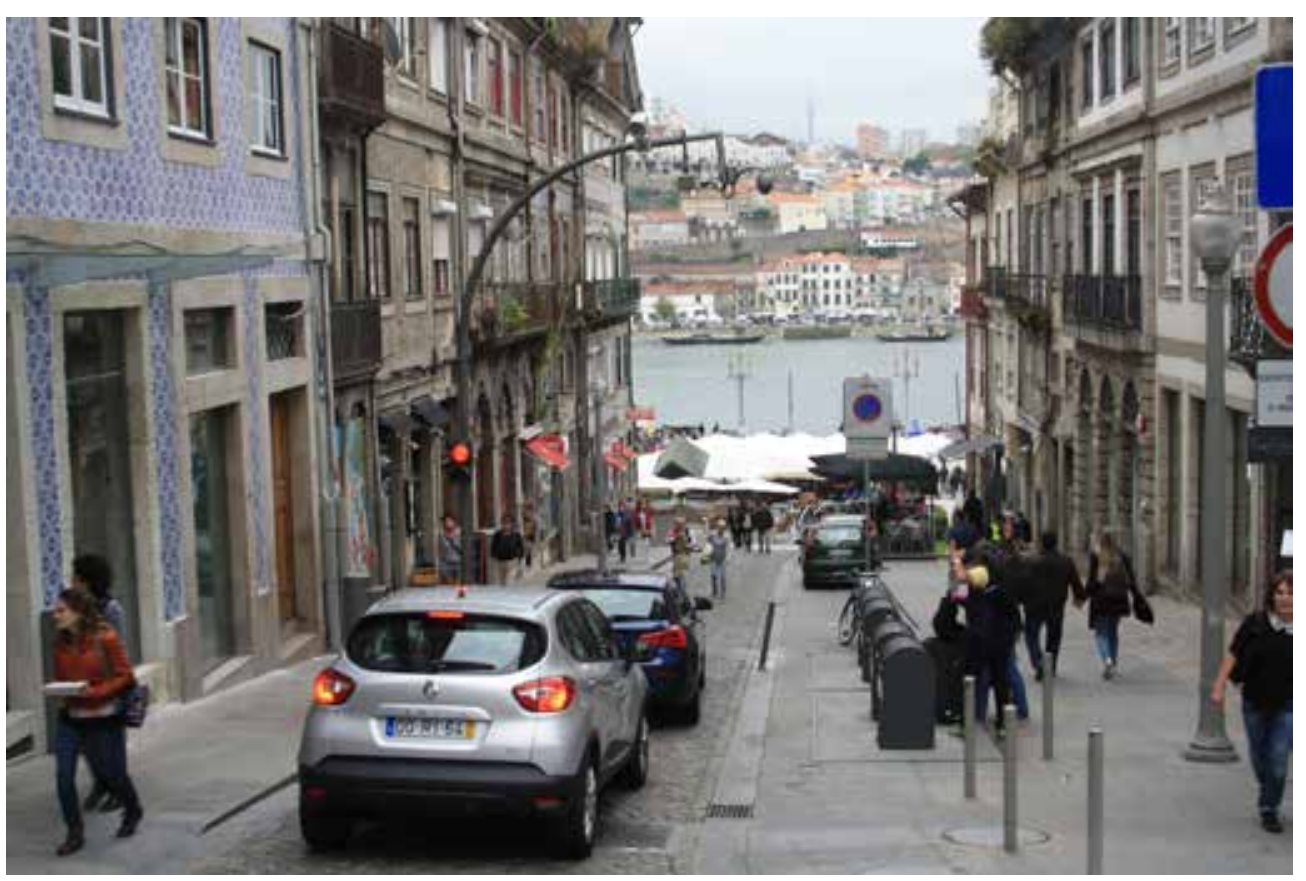

Antiguo edificio de la bolsa. Oporto.

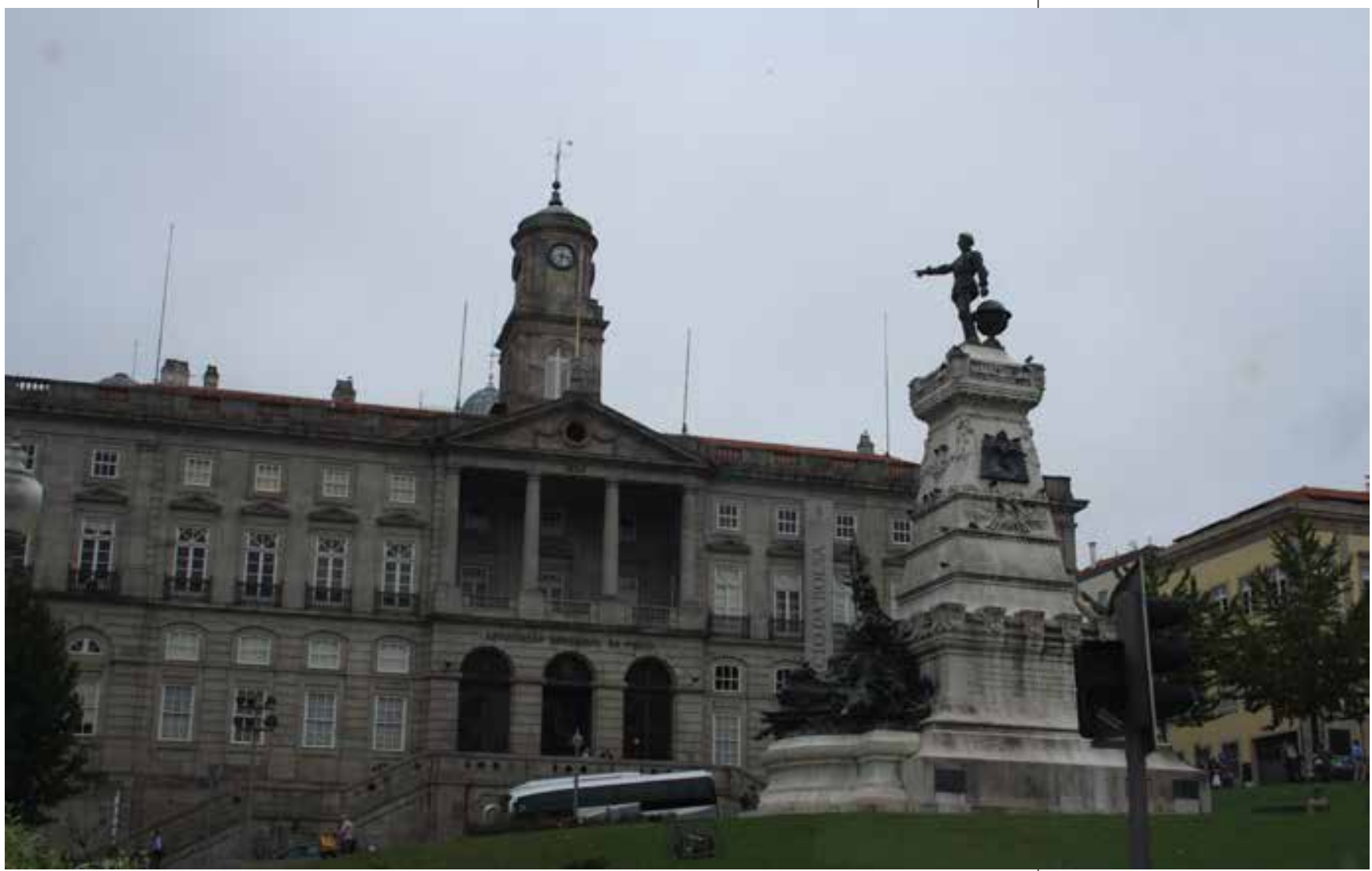




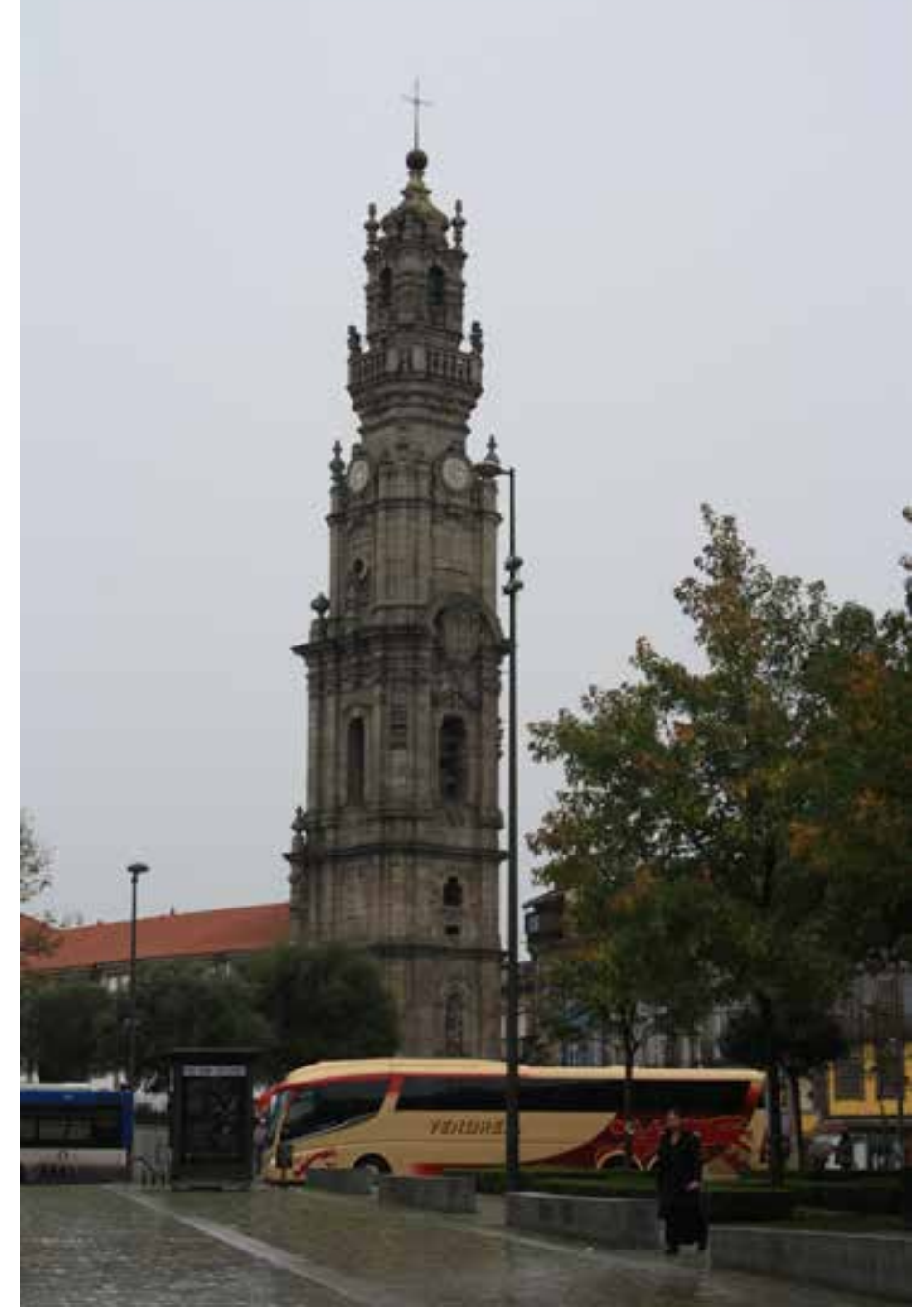

104

Comunicación

número 45

Julio - diciembre

2021

Torre de los Clérigos.

Oporto.

Tranvía en barrio de Oporto.

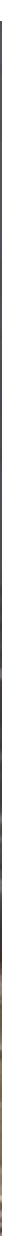




\section{5}

comunicación

número 45

Julio - diciembre

2021

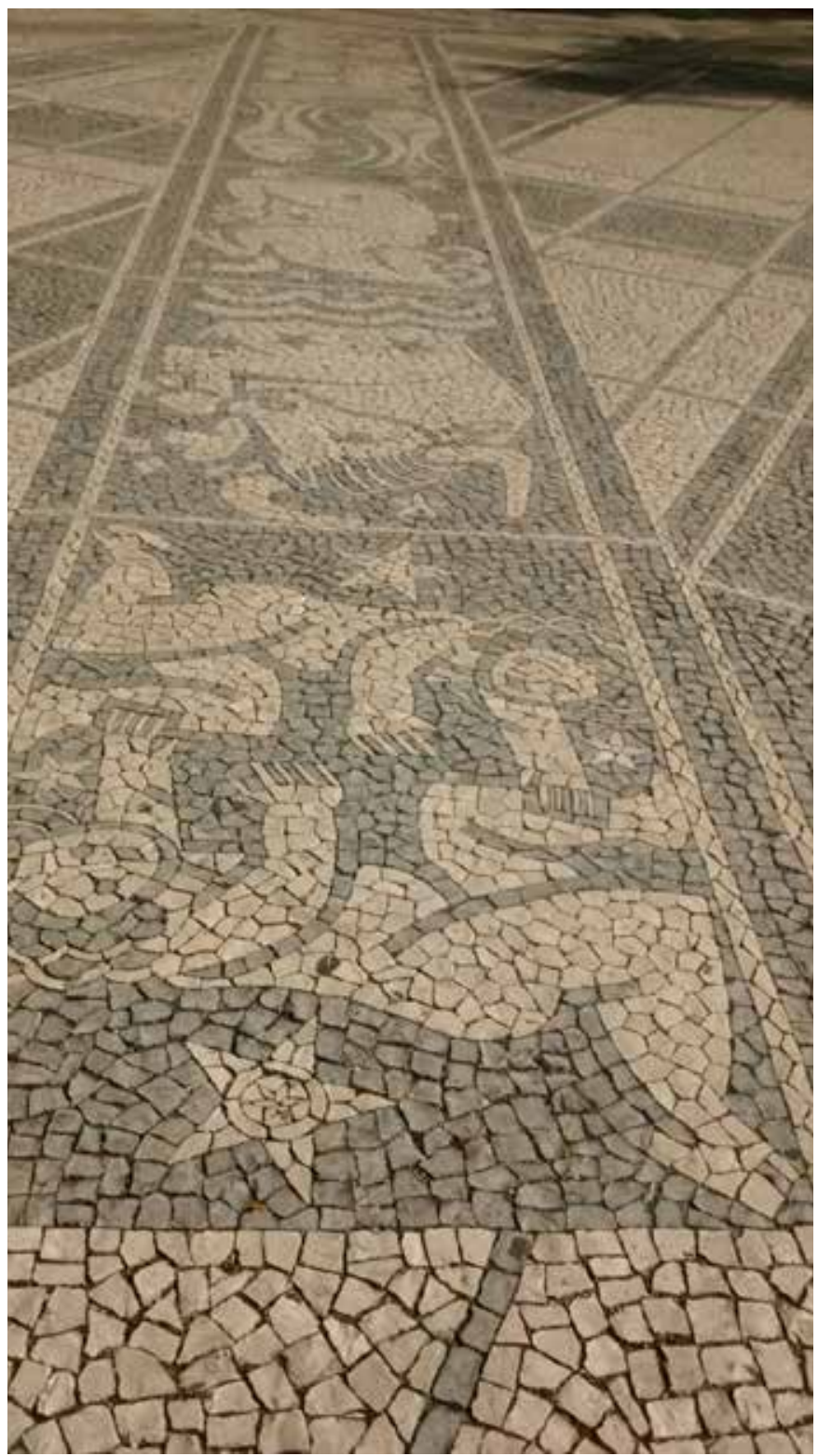

Mosaico aceras sector

de Baixa. Lisboa.

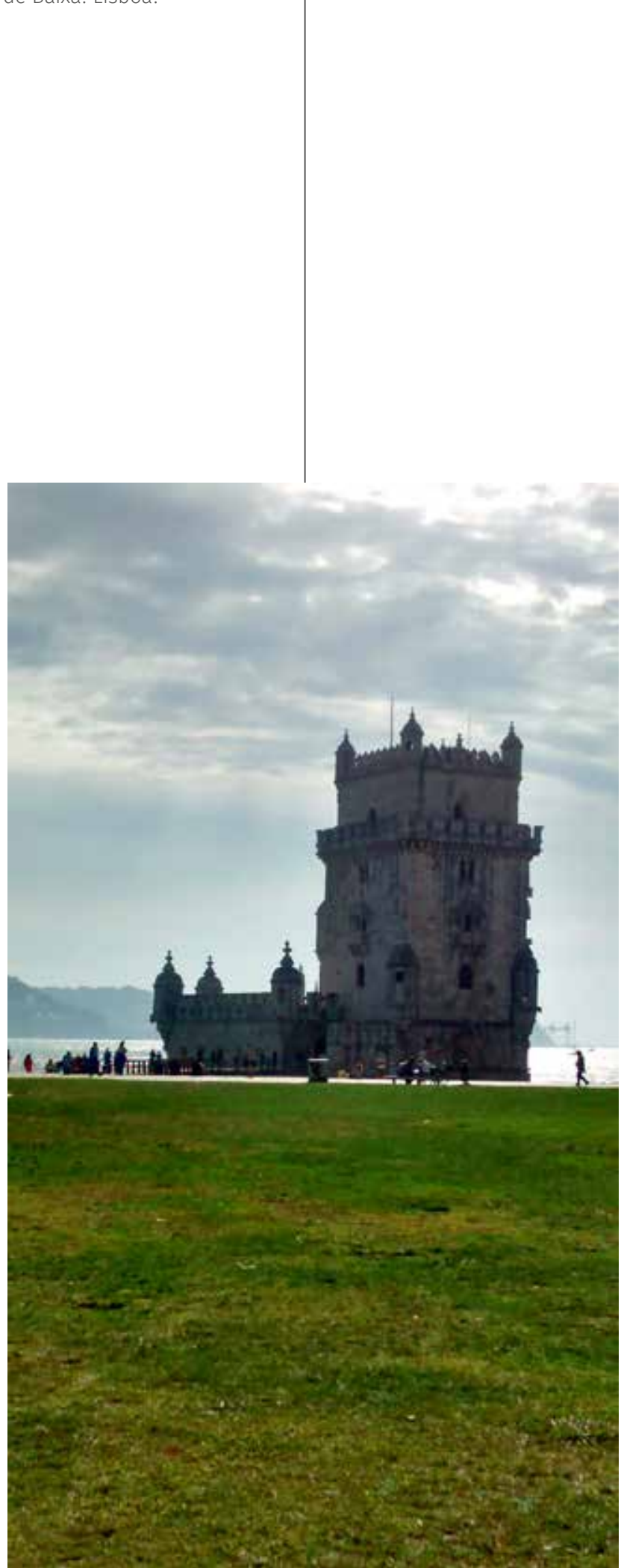

Castillo zona

de Belém. Lisboa. 
comunicación

número 45

Julio - diciembre

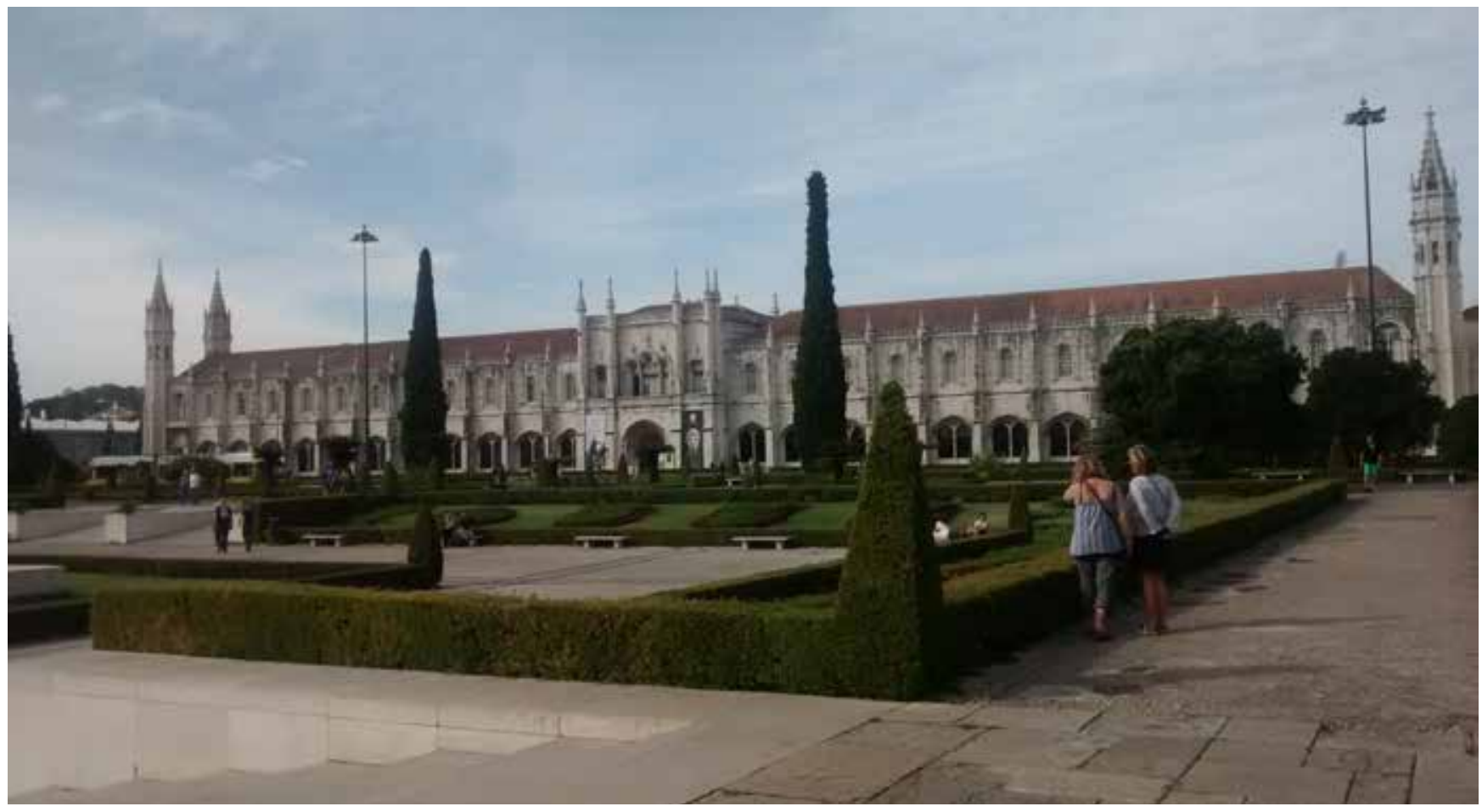

Santuario de la Virgen de Fátima. Lisboa.

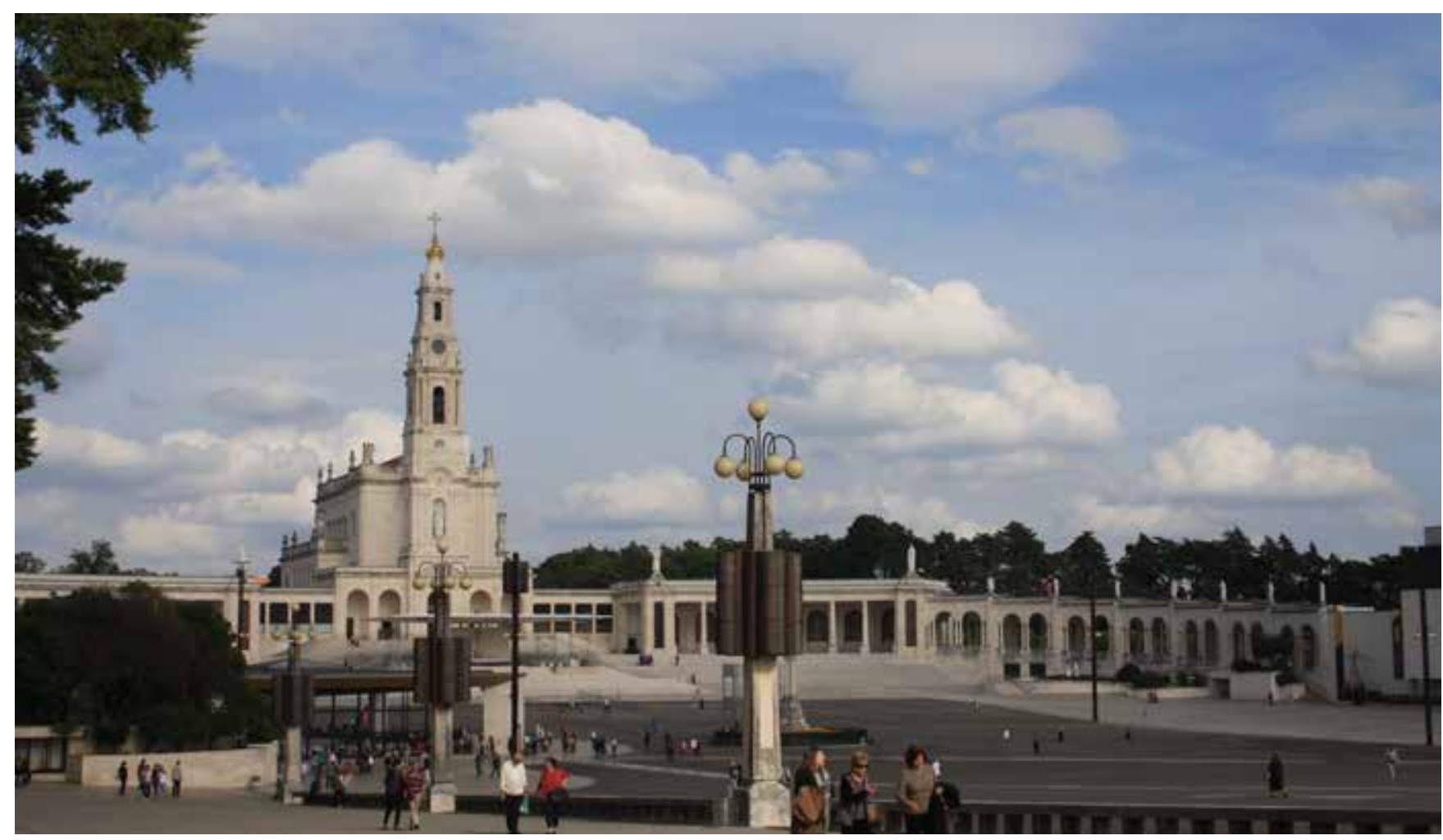

